This document was prepared in conjunction with work accomplished under Contract No. DE-AC09-96SR18500 with the U. S. Department of Energy.

\title{
DISCLAIMER
}

This report was prepared as an account of work sponsored by an agency of the United States Government. Neither the United States Government nor any agency thereof, nor any of their employees, nor any of their contractors, subcontractors or their employees, makes any warranty, express or implied, or assumes any legal liability or responsibility for the accuracy, completeness, or any third party's use or the results of such use of any information, apparatus, product, or process disclosed, or represents that its use would not infringe privately owned rights. Reference herein to any specific commercial product, process, or service by trade name, trademark, manufacturer, or otherwise, does not necessarily constitute or imply its endorsement, recommendation, or favoring by the United States Government or any agency thereof or its contractors or subcontractors. The views and opinions of authors expressed herein do not necessarily state or reflect those of the United States Government or any agency thereof. 
Key Words: Steam Reforming, Aqueous Waste Stabilization, Volume Reduction, Monolithic Waste Form, Granular Waste Form

Retention: Permanent

\section{STABILIZATION OF SAVANNAH RIVER NATIONAL LABORATORY (SRNL) AQUEOUS WASTES BY FLUIDIZED BED STEAM REFORMING (FBSR)}

C.M. Jantzen

J.M. Pareizs

P.R. Burket

November 2004

Immobilization Technology Section Savannah River National Laboratory Aiken, SC 29808
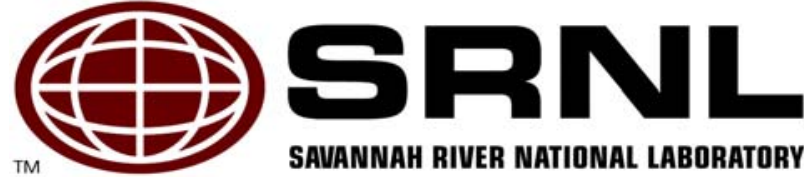

SAVANNAH RIVER NATIONAL LABORATORY

Prepared for the U.S. Department of Energy Under Contract Number DEAC09-96SR18500 


\section{DISCLAIMER}

This report was prepared by Westinghouse Savannah River Company (WSRC) for the United States Department of Energy under Contract No. DE-AC09-96SR18500 and is an account of work performed under that contract. Neither the United States Department of Energy, nor WSRC, nor any of their employees makes any warranty, expressed or implied, or assumes any legal liability or responsibility for the accuracy, completeness, or usefulness, of any information, apparatus, or product or process disclosed herein or represents that its use will not infringe privately owned rights. Reference herein to any specific commercial product, process, or service by trademark, name, manufacturer or otherwise does not necessarily constitute or imply endorsement, recommendation, or favoring of same by WSRC or by the United States Government or any agency thereof. The views and opinions of the authors expressed herein do not necessarily state or reflect those of the United States Government or any agency thereof.

\section{Printed in the United States of America \\ Prepared For \\ U.S. Department of Energy}




\section{STABILIZATION OF SAVANNAH RIVER NATIONAL LABORATORY (SRNL) AQUEOUS WASTES BY FLUIDIZED BED STEAM REFORMING (FBSR)}

C.M. Jantzen

J.M. Pareizs

P.R. Burket

November 2004

Immobilization Technology Section Savannah River National Laboratory Aiken, SC 29808

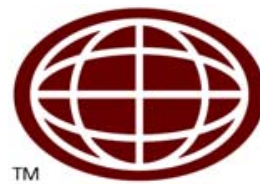




\section{REVIEWS AND APPROVALS}

\section{AUTHOR(S):}

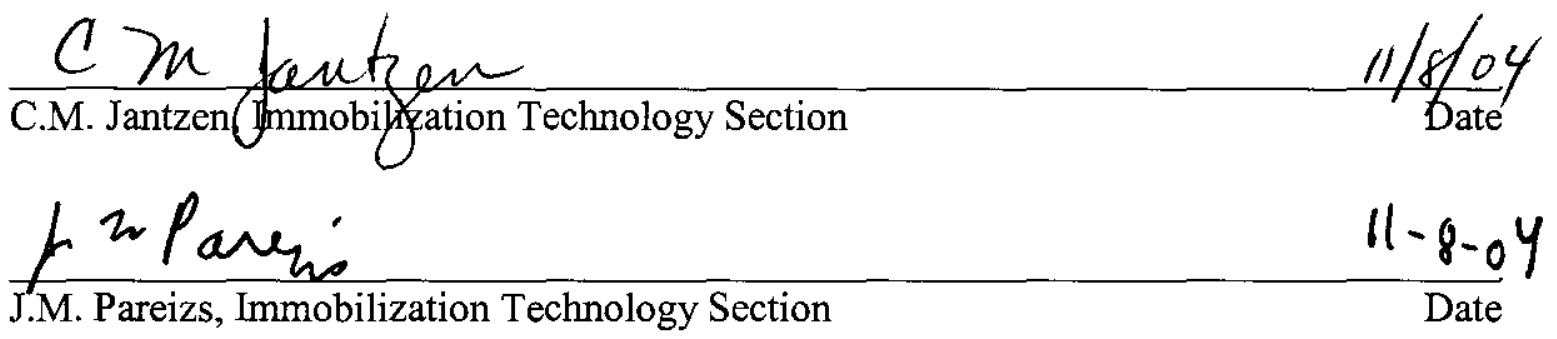

Paus Bunket

P.R. Burkett, Immobilization Technology Section

$11 / 8 / 04$

Date

\section{TECHNICAL REVIEWERS:}

Damer C. Maur

C. Marra, Immobilization Technology Section

$11 / 8 / 04$

Date

\section{APPROVERS}

\section{Enttaetionuto}

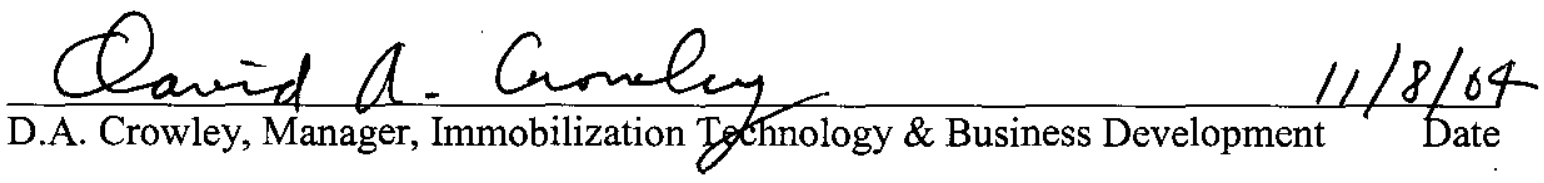

Allan A. Eagrodsuk

A.A. Zagrodnik, SRNL Engineering Section 


\section{EXECUTIVE SUMMARY}

The Savannah River National Laboratory (SRNL) is a multidisciplinary laboratory operated by Westinghouse Savannah River Company (WSRC) in Aiken, South Carolina. Research and development programs have been conducted at SRNL for $~ 50$ years generating non-radioactive (hazardous and non-hazardous) and radioactive aqueous wastes. Typically the aqueous effluents from the R\&D activities are disposed of from each laboratory module via the High Activity Drains (HAD) or the Low Activity Drains (LAD) depending on whether they are radioactive or not. The aqueous effluents are collected in holding tanks, analyzed and shipped to either H-Area (HAD waste) or the F/H Area Effluent Treatment Facility (ETF) (LAD waste) for volume reduction. Because collection, analysis, and transport of LAD and HAD waste is cumbersome and since future treatment of this waste may be curtailed as the F/H-Area evaporators and waste tanks are decommissioned, SRNL laboratory operations requested several proof of principle demonstrations of alternate technologies that would define an alternative disposal path for the aqueous wastes.

Proof of principle for the disposal of SRNL HAD waste using a technology known as Fluidized Bed Steam Reforming (FBSR) is the focus of the current study. The FBSR technology can be performed either as a batch process, e.g. in each laboratory module in small furnaces with an 8 " by 8 " footprint, or in a semi-continuous Bench Scale Reformer (BSR). The proof of principle experiments described in this study cover the use of the FBSR technology at any scale (pilot or full scale). The proof of principle experiments described in this study used a non-radioactive HAD simulant.

The FBSR process produces a granular mineral waste form. The mineral waste form can be sodium carbonate based, sodium silicate based, or sodium aluminosilicate (NAS) based. The aqueous HAD waste is anion rich and cation poor. Therefore additives that provide the cations $\mathrm{Na}^{+}, \mathrm{Ca}^{+2}, \mathrm{Al}^{+3}$, and $\mathrm{Si}^{+4}$ were needed to form the mineral phases. The sodium aluminosilicate (NAS) minerals have cage-like structures that stabilize the $\mathrm{Cl}, \mathrm{F}$, I, other anions and radionuclides in the aqueous laboratory waste and the NAS phases are the preferred mineral host because of these retention qualities.

The FBSR technology was shown to be a suitable technology for disposal of SRNL HAD waste via any number of disposal paths. The FBSR technology is suitable for HAD waste disposal whether the technology is carried out in individual laboratory modules or in a centralized facility within SRNL. The latter, which provides for semi-continuous processing would be a more efficient method of HAD waste disposal.

The FBSR process yields $90-93 \%$ volume reductions as demonstrated in this study. There is $\sim 3925 \mathrm{~L}$ of HAD waste generated in SRNL on a yearly basis. Therefore, FBSR of the HAD waste would create $\sim 575 \mathrm{kgs}$ of solid waste per year. These solids will likely have to be collected and recycled back to a waste or feed tank for subsequent vitrification in the Defense Waste Processing Facility (DWPF) because of the high doses of radioactivity associated with the large volume reductions or disposed of directly into a DWPF canister for burial at the federal Yucca Mtn. Repository. Recycle to DWPF would require a determination of the compatibility of 
the minerals produced with the DWPF process. Previous studies on SRS salt supernates have indicated that the carbonates and silicates are compatible with recycle to DWPF. Disposal at Yucca Mtn. would require qualification of the FBSR NAS mineral waste form as an alternative to vitrification. This study concentrated on producing the NAS FBSR mineral phases because these phases have the best anion and radionuclide retention, can be substituted for DWPF frit, and are the most flexible in terms of disposal paths.

FBSR formulations that can be solidified into a monolith for direct disposal in the SRS burial ground were also investigated in this study. By co-addition of both sodium and calcium silicates, calcium aluminoferrite, and calcium aluminate, the FBSR product can be made naturally cementitious. The addition of the extra co-additives causes a volume increase and therefore a dilution of the radioactivity that may allow the monoliths to meet the SRS burial ground Waste Acceptance Criteria (WAC).

Formation of the NAS granular minerals was successful including retention of the anions and hazardous species. Formation of the naturally monolithic FBSR product was successful. Formation of the granular sodium silicate mineral was not successful in that it did not incorporate the $\mathrm{Cl}$ in the simulated $\mathrm{HAD}$ waste.

Based on the results and conclusions presented in this study, the following recommendations are made:

- Investigations of one or more successful formulations from this study should be verified with radioactive HAD wastes on the batch scale and the semi-continuous BSR scale.

- The hazardous constituent spike used in this study should be analyzed so that the sulfate retention of the FBSR products produced in this study can be better quantified.

- Additional testing such as the Toxic Characteristic Leaching Procedure (TCLP), compressive strength, and Scanning Electron Microscopy (SEM) analyses on the naturally cementitious monoliths should be completed to evaluate the suitability of this form for land disposal.

- Alternative sources of calcium silicates should be investigated to make monolithic waste forms that are naturally cementitious to see if the monolith properties can be improved, e.g. compressive strength

- Fabrication of sodium carbonate FBSR products which may be more compatible with recycle to a waste or feed tank for subsequent vitrification in DWPF should be evaluated

- The use of sodium hydroxide and clay should be more fully investigated because only one test was performed with this combination of co-reactants and this combination of coadditives appeared more promising than the use of other NAS additives.

- Investigate the SRS burial ground Waste Acceptance Criteria (WAC) criteria for FBSR monolith disposal 


\section{TABLE OF CONTENTS}

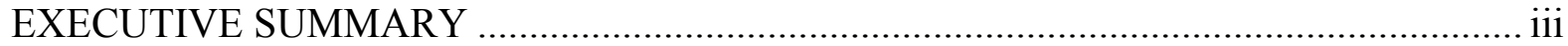

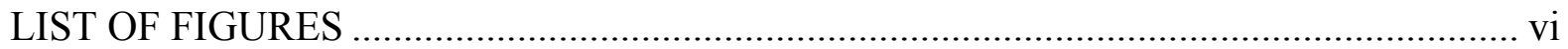

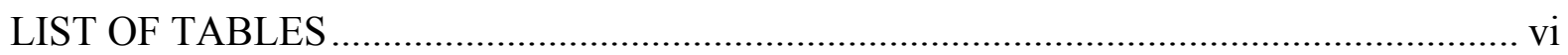

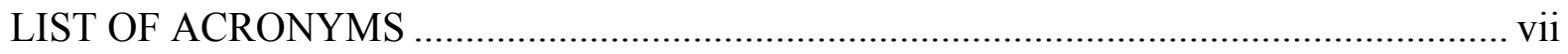

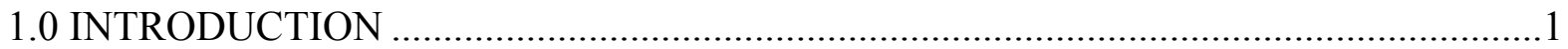

2.0 BACKGROUND: FLUIDIZED BED STEAM REFORMING .......................................

3.0 POTENTIAL APPLICATIONS OF FLUDIZED BED STEAM REFORMING TO SRNL

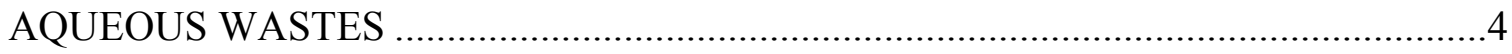

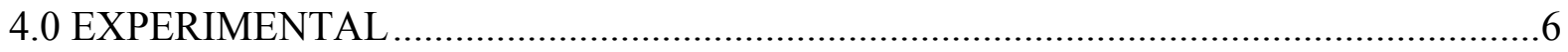

4.1 Preparation of the High Activity Drain Simulant .....................................................6

4.2 Steam Reformer Product Fabrication in Crucibles .................................................

4.3 Steam Reformer Product Fabrication in the SRNL Benchscale Steam Reformer.......12

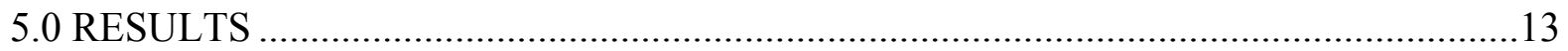

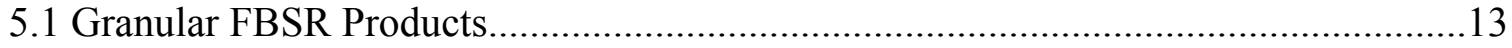

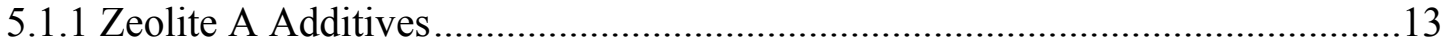

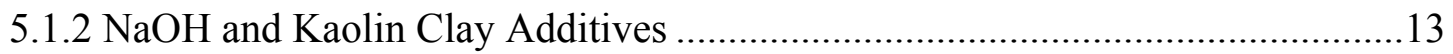

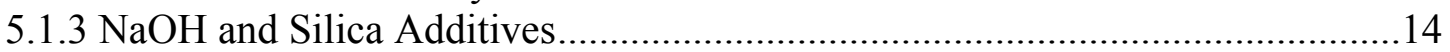

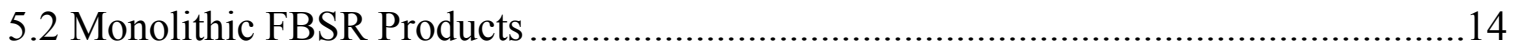

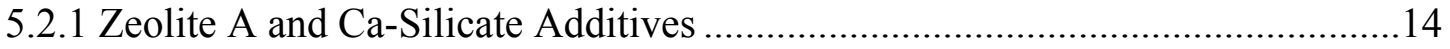

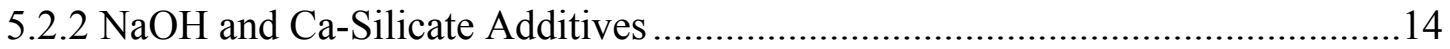

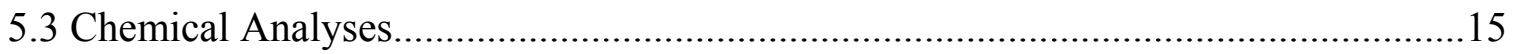

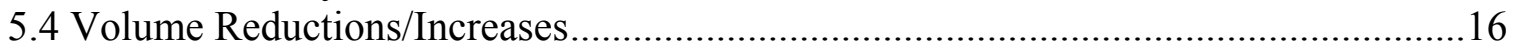

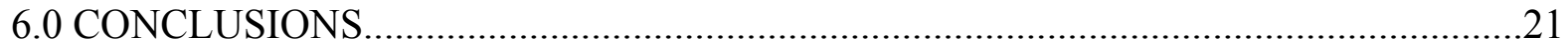

7.0 RECOMMENDATIONS/PATH FORWARD ..........................................................22

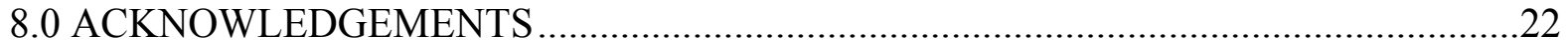

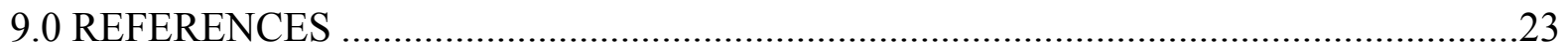




\section{LIST OF FIGURES}

Figure 3-1. FBSR Options Matrix for Laboratory Waste Disposal...................................... 5

Figure 4-1. Ternary phase diagram for the $\mathrm{Na}_{2} \mathrm{O}-\mathrm{SiO}_{2}-\mathrm{Al}_{2} \mathrm{O}_{3}$ system.............................. 10

Figure 4-2. Schematic of the SRNL Benchscale Steam Reformer .................................... 12

Figure 5-1. Photo of Monolithic FBSR Products (Lab 10, Lab 9, and Lab 5) ..................... 15

\section{LIST OF TABLES}

Table 2-1. THOR $^{\text {sm }}$ Pilot Scale Demonstrations with Simulated High Sodium LAW Wastes 3

Table 4-1. Composition of Simulated High Activity Drain Waste...................................... 6

Table 4-2. Elemental Composition of RCRA Metals Solution........................................... 7

Table 4-3. Feldspathoid Minerals Commonly Found in FBSR ........................................ 9

Table 4-4. Summary of Steam Reformer Product Samples ................................................. 11

Table 5-1. Summary of Steam Reformer Product Sample Results..................................... 17

Table 5-2. Anion Concentrations of SRNL HAD Waste Samples After Solidification......... 18

Table 5-3. Cation Concentrations of SRNL HAD Waste Samples After Solidification ........ 19

Table 5-4. Comparison Between Targeted and Measured Sodium, Aluminum, and Silicon

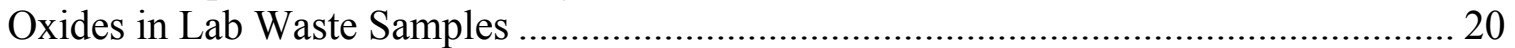

Table 5-5. Volume Reductions/Increases for FBSR HAD Products .................................. 20 
LIST OF ACRONYMS

\begin{tabular}{|l|l|}
\hline BSR & Benchscale Steam Reformer \\
\hline CAA & Clean Air Act \\
\hline CNAS & Calcium Sodium Alumino Silicate \\
\hline DTA & Differential Thermal Analysis \\
\hline DOE & Department of Energy \\
\hline DWPF & Defense Waste Processing Facility \\
\hline EPA & Environmental Protection Agency \\
\hline ETF & Effluent Treatment Facility \\
\hline FBSR & Fluidized Bed Steam Reforming \\
\hline HAD & High Activity Drain \\
\hline HLC & High Level Caves \\
\hline HLW & High Level Waste \\
\hline IC & Ion Chromatography \\
\hline ICP-ES & Inductively Coupled Plasma - Emission Spectroscopy \\
\hline LAD & Low Activity Drain \\
\hline LLRW & Low Level Radioactive Waste \\
\hline MACT & Maximum Achievable Concentration Technology \\
\hline ML & Mobile Laboratory \\
\hline NAS & Sodium Alumino-Silicate \\
\hline OPC & Ordinary Portland Cement \\
\hline RCRA & Resource Conservation and Recovery Act \\
\hline SEM & Scanning Electron Microscopy \\
\hline SRS & Savannah River Site \\
\hline SRNL & Savannah River National Laboratory \\
\hline TCLP & Toxic Characteristic Leaching Procedure \\
\hline THOR & THermal Organic Reduction \\
\hline WAC & Waste Acceptance Criteria \\
\hline WIPP & Waste Isolation Pilot Plant \\
\hline WSRC & Westinghouse Savannah River Co. \\
\hline XRD & X-ray Diffraction \\
\hline & \\
\hline
\end{tabular}




\title{
STABILIZATION OF SAVANNAH RIVER NATIONAL LABORATORY (SRNL) AQUEOUS WASTES BY FLUIDIZED BED STEAM REFORMING (FBSR)
}

\author{
C.M. Jantzen, J.M. Pareizs, P.R. Burket \\ Savannah River National Laboratory \\ Aiken, SC
}

\subsection{INTRODUCTION}

The Savannah River National Laboratory (SRNL) is a multidisciplinary laboratory operated by Westinghouse Savannah River Company (WSRC) in Aiken, South Carolina. Research and development programs have been conducted at SRNL for $\sim 50$ years generating non-radioactive (hazardous and non-hazardous) and radioactive waste materials. This study addresses only the liquid wastes generated from the laboratories area. These include [1]:

- Low-activity aqueous wastes which may or may not be hazardous due to mercury or organic content. These include process water and waste from non-radioactive chemical experiments. These wastes are typically disposed of in laboratory modules via Low-Activity Drains (LAD).

- High-activity aqueous waste from chemical experiments in the laboratories and in the Shielded Cells. This waste may or may not be hazardous due to mercury and/or organic content. These wastes are typically disposed of in laboratory modules via High-Activity Drains (HAD).

Typically the LAD and HAD aqueous effluents from the technical area are collected in 5,900 gallon and 3,670 gallon holding tanks fitted with agitators, in 776-A. When a tank is nearly full, a well-mixed sample is taken and sent for routine analyses. If the waste meet acceptable limits [1] the HAD waste can be shipped to an H-Area evaporator for volume reduction. The transfer is by steam jet in 776-A to a tanker trailer that holds approximately 4,000 gallons. For LAD aqueous wastes the tanker is not shielded. For HAD aqueous wastes the tanker trailer is shielded. The HAD wastes are shipped to H-Canyon and LAD wastes to the F/H Effluent Treatment Facility (ETF).

Because collection, analysis, and transport of LAD and HAD waste to H-Area is cumbersome and since future treatment of this waste may be curtailed as the F/H-Area evaporators and waste tanks are decommissioned, research and development efforts have been initiated within SRNL to determine a disposal path for these wastes that is not dependent on H-Area evaporators and ETF. The development of an alternative waste disposal technology for SRNL LAD and HAD waste 
will enable SRNL research and development activities to be independent of other radioactive facilities on the Savannah River Site (SRS).

The first phase of the investigation was to determine the feasibility of four different alternative disposal methods for HAD waste: Solidification/Stabilization, Local Treatment at Point of Contact, FBSR, and Hybrid Microwave Technology. The objective of the first phase was to perform proof of principal scoping tests for each of the selected technologies. This report presents the results for the FBSR feasibility tests on a non-radioactive HAD simulant.

\subsection{BACKGROUND: FLUIDIZED BED STEAM REFORMING (FBSR)}

Studsvik built and tested a commercial Low-Level Radioactive Waste (LLRW) FBSR Processing Facility in Erwin, TN, in 1999. In January 2000, commercial operation commenced [2]. The Erwin Facility has the capability to safely and efficiently receive and process a wide variety of solid and liquid LLRW streams including: ion exchange resins, charcoal, graphite, sludge, oils, solvents, and cleaning solutions with contact radiation levels of up to $100 \mathrm{R} / \mathrm{hr}$. The licensed and heavily shielded SPF can receive and process liquid and solid LLRWs with high water and/or organic content. The solid product produced is volume reduced during processing, drummed, and sent to Barnwell for final disposal.

The Erwin facility employs the THermal Organic Reduction $\left(\mathrm{THOR}^{\mathrm{sm}}\right)$ process, developed by Studsvik, which utilizes pyrolysis*/steam reforming technology. THOR ${ }^{\mathrm{sm}}$ reliably and safely processes a wide variety of LLRW's in a unique, moderate temperature $\left(\sim 700^{\circ} \mathrm{C}\right)$, dual-stage, pyrolysis/reforming, fluidized bed treatment system. The reforming process has demonstrated effectiveness in volatilizing/combusting organics and separating sulfur and halogens from inorganic waste materials. Of special relevance is the capability of the $\mathrm{THOR}^{\mathrm{sm}}$ technology to convert nitrates to nitrogen and sodium salts to sodium compounds that are suitable for direct disposal and/or subsequent vitrification.

In the THOR ${ }^{\mathrm{sm}}$ FBSR process, a granular/particle bed material is fluidized with low pressure superheated steam. Pyrolysis is not combustion as no oxygen is present; therefore the FBSR technology is Environmental Protection Agency (EPA) Clean Air Act Maximum Achievable Concentration Technology (CAA/MACT) compliant.

$\mathrm{THOR}^{\mathrm{sm}}$ performed $11>10$ pilot scale demonstrations on high Na containing Hanford salt simulants. The liquid waste was mixed in a batch/feed tank with selected co-reactants, including the additives necessary to make the final product into any of the following product phases (Table 2-1):

- $\mathrm{Na}_{2} \mathrm{CO}_{3}$ (no additives needed)

- $\mathrm{Na}_{2} \mathrm{SiO}_{3}\left(\mathrm{SiO}_{2}\right.$ added $)$

- Na aluminosilicates (kaolin clay added)

* Pyrolysis chemically decomposes organic materials by heat in the absence of oxygen, e.g. $\mathrm{C}_{\mathrm{x}} \mathrm{H}_{\mathrm{y}}+\mathrm{Heat} \rightarrow \mathrm{CH}_{4}+\mathrm{C}$. 
WSRC-TR-2004-00532

Revision 0

Table 2-1. THOR $^{\text {sm }}$ Pilot Scale Demonstrations with Hanford High Sodium Wastes

\begin{tabular}{|c|c|c|c|}
\hline $\begin{array}{l}\text { Number } \\
\text { of Pilot } \\
\text { Demon- } \\
\text { strations }\end{array}$ & Additive & Mineral Product & Product Application \\
\hline 5 & Clay & $\begin{array}{l}\text { Sodium aluminosilicates such as } \\
\text { nepheline }\left(\mathrm{NaAlSiO}_{4}\right) \text {, sodalite } \\
\left(\mathrm{Na}_{6}\left[\mathrm{Al}_{6} \mathrm{Si}_{6} \mathrm{O}_{24}\right](2 \mathrm{NaCl})\right) \text {, and } \\
\text { nosean }\left(\mathrm{Na}_{6}\left[\mathrm{Al}_{6} \mathrm{Si}_{6} \mathrm{O}_{24}\right]\left(\mathrm{Na}_{2} \mathrm{SO}_{4}\right)\right) \\
\text { that can stabilize problematic } \\
\text { anions such as } \mathrm{Cl}, \mathrm{F} \text {, and } \mathrm{SO}_{4}\end{array}$ & $\begin{array}{l}\text { FBSR product may be acceptable } \\
\text { as a final mineral waste form for } \\
\text { land disposal, Yucca Mountain, } \\
\text { Waste Isolation Pilot Plant } \\
\text { (WIPP), etc. } \\
\text { In small quantities the FBSR } \\
\text { product would likely be } \\
\text { compatible with subsequent } \\
\text { vitrification as a frit substitute. }\end{array}$ \\
\hline 3 & $\begin{array}{l}\text { Sand or } \\
\text { Silica }\end{array}$ & Sodium silicate & $\begin{array}{l}\text { FBSR product may be acceptable } \\
\text { as a final mineral waste form for } \\
\text { disposal at WIPP. } \\
\text { FBSR product may be used as a } \\
\text { partial frit replacement in HLW } \\
\text { melter. }\end{array}$ \\
\hline 3 & $\mathrm{CO}_{2}$ & Sodium carbonate & $\begin{array}{l}\text { FBSR product may be acceptable } \\
\text { as a final mineral waste form for } \\
\text { disposal at WIPP. } \\
\text { FBSR product may be used as a } \\
\text { partial frit replacement in HLW } \\
\text { melter. }\end{array}$ \\
\hline
\end{tabular}

Several chemical and physical reactions take place in the steam reformer:

- Evaporation of all liquid

- Denitration of the nitrates and nitrites $(>99 \%)$ in the waste feed into nitrogen gas by the reductants added

- Conversion of organics into $\mathrm{CO}_{2}$

- Reduction and stabilization of hazardous metals, e.g. $\mathrm{Cr}^{+6}$ is reduced to a nonhazardous valence state, e.g. $\mathrm{Cr}^{+3}$

The FBSR technology has been demonstrated to be effective at remediation of the following:

- Hanford Low Activity Waste into either carbonates or silicates that can subsequently be vitrified [3]

- Hanford Low Activity Waste and SRS salt supernate into a final waste form (aluminosilicate mineral) for land disposal $[3,4,5]$ 
- INEEL Sodium Bearing Waste into a carbonate form acceptable to WIPP as a final waste form [6]

- $\quad$ SRS T48 HLW supernate with tetraphenyl borate into either carbonates or silicates that are compatible with subsequent vitrification in DWPF [7, 8]

- SRS Low-Curie and High-Curies salt supernates [9] into carbonate, silicate, and NAS mineral forms for burial at WIPP or Yucca Mtn.

This latter study demonstrated that the FBSR reactions can be duplicated in $\mathrm{Al}_{2} \mathrm{O}_{3}$ crucibles in small laboratory scale furnaces that fit into most SRS laboratory module hoods. All demonstrations to date have been performed with high $\mathrm{pH}(\sim 14)$ SRS salt supernate simulants including high $\mathrm{OH}$ and high $\mathrm{NO}_{3}$ simulants.

\subsection{POTENTIAL APPLICATIONS OF FLUIDIZED BED STEAM REFORMING TO SRNL AQUEOUS WASTES}

In order for the FBSR technology to be applicable to SRNL laboratory wastes a demonstration on an acidic laboratory waste simulant was needed. The FBSR Technology would allow SRNL's Laboratory waste to be remediated in any of the following ways (see also Figure 3-1):

- LAD waste could be sent to Erwin for processing into a solid carbonate, silicate, or aluminosilicate mineral form that could be disposed of in WIPP if found to be classified as TRU waste after concentration

- LAD waste could be sent to Erwin for processing into a solid aluminosilicate mineral form that could be disposed of in Barnwell or the SRS burial ground if found to be classified as non-TRU waste after concentration

- HAD waste, if volume reduced, could be processed in a semi-continuous BSR facility operated within SRNL, e.g. processed into a solid carbonate or silicate form that could be disposed of in a DWPF waste tank for subsequent vitrification

- HAD waste, if volume reduced, could be processed on a laboratory module scale in small furnaces, e.g. processed into a solid carbonate or silicate form that could be collected in the SRNL High Level Caves (HLC) and shipped to a DWPF waste or feed tank for subsequent vitrification or disposal directly into a HLW canister for shipment to Yucca Mtn.

- HAD waste, if volume increased, could be processed on a laboratory module scale or in a BSR operated in one wing of the building and solidified into a monolith for on site burial depending on the SRS burial ground Waste Acceptance Criteria (WAC)

Moreover, FBSR is being looked at for remediation of other "orphan" wastes at SRS and there is a possibility that an FBSR facility may be built at SRS for stabilization of these wastes. 
The experiments discussed in this report focus on SRNL HAD waste disposal by the FBSR technology on a batch laboratory module scale, e.g. in small furnaces, and in a semi-continuous Bench Scale Reformer (BSR). FBSR formulations that are silicate based are investigated for recycle to a DWPF processing tank for subsequent vitrification. FBSR formulations that are sodium aluminosilicate (NAS) based are investigated for recycle to a DWPF processing tank for subsequent vitrification or direct disposal in WIPP or Yucca Mtn. FBSR formulations that can be solidified into a monolith for direct disposal in the SRS burial ground are also investigated. This proof of principle will cover the use of FBSR technology at any scale (pilot or full scale) in the future.

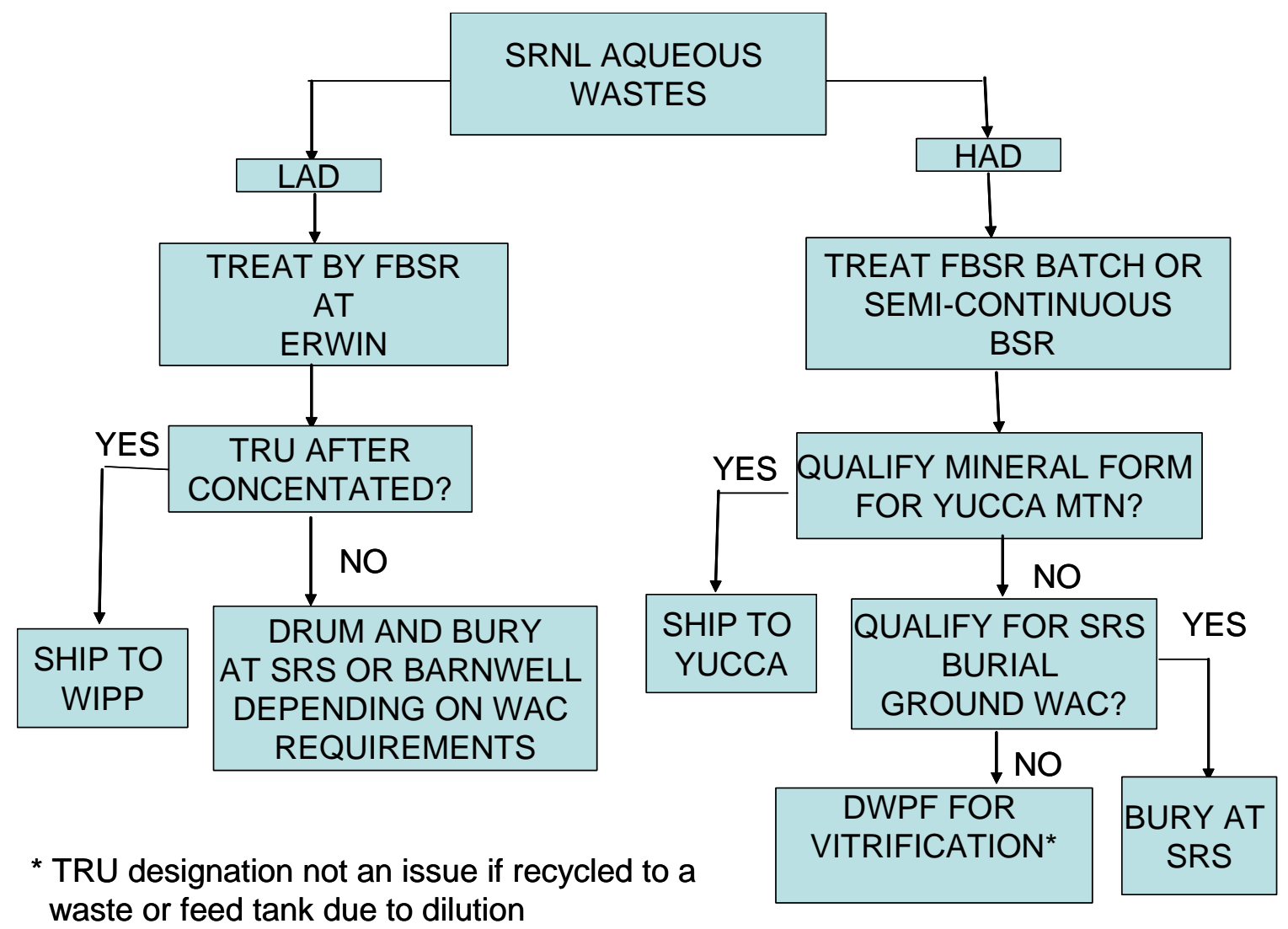

Figure 3-1. FBSR Options Matrix for Laboratory Waste Disposal. 


\subsection{EXPERIMENTAL}

\subsection{Preparation of the High Activity Drain Simulant}

A simulated (non-radioactive) High Activity Drain (HAD) waste was prepared by the SRNL Mobile Lab. The simulated waste was a mixture of the following types of sludge and glass dissolutions typical of 773-A B-wing aqueous wastes before neutralization and disposal in the HAD:

$8 \mathrm{~L}$ of mixed acid sample digestion $\left(\mathrm{HF} / \mathrm{HNO}_{3} / \mathrm{HCl} / \mathrm{H}_{3} \mathrm{BO}_{3}\right.$ acids)

$8 \mathrm{~L}$ of aqua regia ( $\mathrm{HCl} / \mathrm{HNO}_{3}$ acids)

$8 \mathrm{~L}$ of sodium peroxide/sodium hydroxide fusion $\left(\mathrm{Na}_{2} \mathrm{O}_{2} / \mathrm{NaOH} / \mathrm{HCl}\right)$

The chemical composition of the simulant is given in Table 4-1.

Table 4-1. Composition of Simulated High Activity Drain Waste

\begin{tabular}{|c|c|c|c|}
\hline Analyte & $\begin{array}{c}\text { Concentration } \\
\text { (mg/L) }\end{array}$ & Analyte & $\begin{array}{c}\text { Concentration } \\
\text { (mg/L) }\end{array}$ \\
\hline $\mathrm{Ag}^{\dagger}$ & 0.131 & $\mathrm{Na}^{\dagger}$ & 2750 \\
\hline $\mathrm{Al}^{\dagger}$ & 45.2 & $\mathrm{Ni}^{\dagger}$ & 3.44 \\
\hline $\mathrm{As}^{\dagger}$ & $<0.120$ & $\mathrm{P}^{\dagger}$ & 0.376 \\
\hline $\mathrm{B}^{\dagger}$ & 541 & $\mathrm{~Pb}^{\dagger}$ & $<0.020$ \\
\hline $\mathrm{Ba}^{\dagger}$ & 0.454 & $\mathrm{~S}^{\dagger}$ & 1.65 \\
\hline $\mathrm{Ca}^{\dagger}$ & 17.6 & $\mathrm{Se}^{\dagger}$ & $<0.120$ \\
\hline $\mathrm{Cd}^{\dagger}$ & $<0.010$ & $\mathrm{Si}^{\dagger}$ & 150 \\
\hline $\mathrm{Cr}^{\dagger}$ & 0.478 & $\mathrm{Sr}^{\dagger}$ & 0.125 \\
\hline $\mathrm{Cu}^{\dagger}$ & 1.43 & $\mathrm{Ti}^{\dagger}$ & 1.95 \\
\hline $\mathrm{Fe}^{\dagger}$ & 106 & $\mathrm{Zn}^{\dagger}$ & 1.59 \\
\hline $\mathrm{K}^{\dagger}$ & 14.9 & $\mathrm{Zr}^{\dagger}$ & 2.67 \\
\hline $\mathrm{Li}^{\dagger}$ & 166 & $\mathrm{~F}^{-\dagger}$ & 1460 \\
\hline $\mathrm{Mg}^{\dagger}$ & 10.4 & $\mathrm{Cl}^{\dagger}$ & 6500 \\
\hline $\mathrm{Mn}^{\dagger}$ & 16.4 & $\mathrm{NO}_{3}{ }^{\dagger}$ & 21300 \\
\hline
\end{tabular}

${ }^{\dagger}$ From ICP-ES

${ }^{\ddagger}$ From IC

Because SRNL HAD waste is EPA Resource Conservation and Recovery Act (RCRA) characteristically hazardous, $15 \mathrm{~mL}$ of a RCRA metals spike solution (see Table 4-2 for solution composition) was added per $\mathrm{L}$ of the simulated HAD waste. 
Table 4-2. Elemental Composition of RCRA Metals Solution

\begin{tabular}{|l|c|c|}
\hline \multicolumn{1}{|c|}{ Metal } & $\begin{array}{c}\text { Concentration in RCRA } \\
\text { Metals Solution } \\
\text { (mg/L) }\end{array}$ & $\begin{array}{c}\text { Concentration in } \\
\text { Solution with 15 mL } \\
\text { Metals Solution per 1 L } \\
\text { HAD Waste Simulant } \\
\text { (mg/L) }\end{array}$ \\
\hline Antimony & 75.0 & 1.15 \\
\hline Arsenic & 326.2 & 5 \\
\hline Beryllium & 79.6 & 1.22 \\
\hline Cadmium & 7.2 & 0.11 \\
\hline Lead & 48.9 & 0.75 \\
\hline Selenium & 65.2 & 1 \\
\hline Thallium & 13.0 & 0.2 \\
\hline Vanadium & 104.4 & 1.6 \\
\hline Zinc & 280.5 & 4.3 \\
\hline
\end{tabular}

\subsection{Steam Reformer Product Fabrication in Crucibles}

Three processes were used for fabricating the steam reforming product in crucibles. In the one step process, lab waste is mixed with a solid co-reactant such as clay or silica and sucrose. The sucrose assists in the denitration allowing it to occur at lower temperatures than it would in the absence of sucrose. The sucrose also drives the nitrates and nitrites to $\mathrm{N}_{2}$ instead of $\mathrm{NO}_{\mathrm{x}}$ as indicated in Equation 1 and Equation 2. The amount of sucrose added to all the experiments was $2 \mathrm{X}$ the stoichiometric amount indicated by Equation 1 and Equation 2.

Equation $1 \quad \mathrm{C}_{12} \mathrm{H}_{22} \mathrm{O}_{11}+9.6 \mathrm{NaNO}_{3} \rightarrow 7.2 \mathrm{CO}_{2}+11 \mathrm{H}_{2} \mathrm{O}+4.8 \mathrm{Na}_{2} \mathrm{CO}_{3}+4.8 \mathrm{~N}_{2}$

Equation $2 \quad \mathrm{C}_{12} \mathrm{H}_{22} \mathrm{O}_{11}+16 \mathrm{NaNO}_{2} \rightarrow 4 \mathrm{CO}_{2}+11 \mathrm{H}_{2} \mathrm{O}+8 \mathrm{Na}_{2} \mathrm{CO}_{3}+8 \mathrm{~N}_{2}$

The aqueous waste, co-reactant, and sucrose are dried to a peanut butter-like consistency at $50^{\circ} \mathrm{C}$ to avoid splatter, and heated to $725^{\circ} \mathrm{C}$ for 24 hours, all in a $100 \mathrm{~mL} \mathrm{Al}_{2} \mathrm{O}_{3}$ open crucible in a

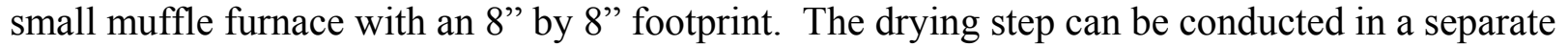
drying oven to accommodate $\sim 1000 \mathrm{~mL}$ of HAD waste at a time. Alternatively, larger crucibles and a larger oven can be used depending on the volume of wastes to be remediated. The one step process reproduces the evaporation, denitration, organic destruction, and anhydrous mineralization that occur during the FBSR process. While the 1 step process does not allow for the hydrothermal reactions to occur that would occur in a continuous or semi-continuous FBSR, it does produce the mineral phases of interest. This is the simplest small scale static FBSR process that can effectively be carried out in a single laboratory module hood. The one step process is, therefore, the preferred process if the waste remediation is to occur on a laboratoryby-laboratory module basis. 
The 2 step process is the same as the one step process, but after heating at $725^{\circ} \mathrm{C}$ the product from the crucible is wetted and is placed in a Parr pressure vessel (sealed) for 24 hours at $90^{\circ} \mathrm{C}$. The two step process reproduces the evaporation, denitration, organic destruction, and hydrothermal mineralization that occur during the FBSR process.

The three step process adds an additional heating to the two step process -24 hours at $725^{\circ} \mathrm{C}$ in an open crucible to drive off waters of hydration from the mineralization that occurred during hydrothermal processing in the Parr pressure vessels. Table 4-4 is a summary of the steam reformer product samples prepared for this study. Included in the table are target products, number of steps, simulant amount, and reagents, including sucrose.

The SRNL aqueous laboratory waste is anion rich and cation poor (Table 4-1). Therefore additives that provided the cations $\mathrm{Na}^{+}, \mathrm{Ca}^{+2}, \mathrm{Al}^{+3}$, and $\mathrm{Si}^{+4}$ were needed to form the feldspathoid minerals (Table 4-3). These minerals have cage-like structures that stabilize the $\mathrm{Cl}, \mathrm{F}$, I, other anions and radio-nuclides in the aqueous laboratory waste. Two different sources of $\mathrm{Na}^{+}$were used during experimentation, commercially available Zeolite- $\mathrm{A}\left(\mathrm{Na}_{12}\left[\mathrm{Al}_{12} \mathrm{Si}_{12} \mathrm{O}_{48}\right] \cdot 27 \mathrm{H}_{2} \mathrm{O}\right)$ and $\mathrm{NaOH}$ plus kaolin clay (Table 4-4). Once source of $\mathrm{Ca}^{+2}$ was used during experimentation, Ordinary Portland Cement (OPC).

Recent experimentation [9] has demonstrated that the formation of the sodium aluminosilicate feldspathoid minerals is well described by the known ternary phase diagram for the $\mathrm{Na}_{2} \mathrm{O}_{-} \mathrm{Al}_{2} \mathrm{O}_{3}-$ $\mathrm{SiO}_{2}$ system (Figure 4-1 [10]). The successful Hanford AN-107 mineral waste form made by $\mathrm{THOR}^{\mathrm{SM}}[2,3,4]$ is shown on the ternary phase diagram as the light rectangle and represents the target sodium aluminosilicate (NAS) mineral phase for the SRNL laboratory waste stabilization. The laboratory waste composition from Table 4-1 is converted to a calcine basis (composition once evaporated and denitrated) and shown by the star on $\mathrm{SiO}_{2}-\mathrm{Al}_{2} \mathrm{O}_{3}$ binary side of the ternary diagram. The dark triangle represents the composition of the Zeolite-A additive. The dark rectangle represents the composition of the clay and $\mathrm{NaOH}$ mixture added.

Lab experiments \# 1, 2, 3, 6, 7, and 8 were all formulated to make the target NAS mineral phases similar to the AN-107 in granular form (Figure 4-1). These mineral forms may be able to be disposed of in the SRS burial ground and/or recycled to the DWPF feed tank for subsequent vitrification due to the small quantity of NAS that will be formed (see Section 5.3). Laboratory 4 was formulated to make $\mathrm{Na}_{2} \mathrm{SiO}_{3}$ which would also be acceptable to DWPF as a frit substitute but probably not acceptable as a waste form for burial. The NAS and $\mathrm{Na}_{2} \mathrm{SiO}_{3}$ starting additives and target compositions are all shown on Figure 4-1.

The chemistry for the calcium sodium aluminosilicates (CNAS) in quaternary composition space are not as easily diagramed but have the advantage that they are naturally cementitious after mineralization at $725^{\circ} \mathrm{C}$. Therefore, they can be set into blocks or cylinders for direct disposal. Lab experiments \#5, 9 and 10 were attempted in order to make a naturally monolithic waste form for direct disposal (Table 4-4). 
WSRC-TR-2004-00532

Revision 0

Table 4-3. Feldspathoid Minerals Commonly Found in FBSR

\begin{tabular}{|c|c|c|c|c|c|}
\hline $\begin{array}{l}\text { Substitution In } \\
\text { Cage Structure }\end{array}$ & Chemical Formula & $\begin{array}{l}\text { Common or } \\
\text { Mineral Name }\end{array}$ & $\begin{array}{l}\text { Density } \\
\text { (g/cm3) }\end{array}$ & $\begin{array}{l}\text { Crystal } \\
\text { Type }\end{array}$ & Ref. \\
\hline \multicolumn{6}{|l|}{ Precursor } \\
\hline NONE & $\mathrm{Na}_{12}\left[\mathrm{Al}_{12} \mathrm{Si}_{12} \mathrm{O}_{48}\right] \bullet 27 \mathrm{H}_{2} \mathrm{O}$ & Zeolite-A & $1.99^{\sharp}$ & Cubic & 11,13 \\
\hline \multicolumn{6}{|c|}{ Nephelines and Stuffed Cristobalites } \\
\hline UNKNOWN & $(\mathrm{K}, \mathrm{Na}) \mathrm{AlSiO}_{4}$ & Nepheline & 2.63 & Hexagonal & PDF\#35-424 \\
\hline UNKNOWN & $\mathrm{NaAlSiO}_{4}$ & Carnegeite & 2.401 & Cubic & PDF \#11-221 \\
\hline UNKNOWN & $\left(\mathrm{Na}_{2} \mathrm{O}\right) \leq 0.33 \mathrm{NaAlSiO}{ }_{4}$ & Na rich Nepheline & 2.64 & Cubic & PDF \#39-101 \\
\hline UNKNOWN & $\mathrm{Na}_{1.45} \mathrm{Al}_{1.45} \mathrm{Si}_{0.55} \mathrm{O}_{4}$ & Stuffed Cristobalite & 2.62 & Cubic & PDF \#49-2 \\
\hline UNKNOWN & $\mathrm{Na}_{1.95} \mathrm{Al}_{1.95} \mathrm{Si}_{0.05} \mathrm{O}_{4}$ & Stuffed Cristobalite & 2.72 & Tetragonal & PDF \# 49-3 \\
\hline UNKNOWN & $\mathrm{Na}_{1.75} \mathrm{Al}_{175} \mathrm{Si}_{0.25} \mathrm{O}_{4}$ & Stuffed Cristobalite & 2.72 & Orthorhombic & PDF \# 49-4 \\
\hline UNKNOWN & $\mathrm{Na}_{1.65} \mathrm{Al}_{165} \mathrm{Si}_{0.35} \mathrm{O}_{4}$ & Stuffed Cristobalite & 2.69 & Tetragonal & PDF \# 49-5 \\
\hline UNKNOWN & $\mathrm{Na}_{1.55} \mathrm{Al}_{155} \mathrm{Si}_{045} \mathrm{O}_{4}$ & Stuffed Cristobalite & 2.674 & Orthorhombic & PDF \# 49-6 \\
\hline UNKNOWN & $\mathrm{Na}_{1.15} \mathrm{Al}_{115} \mathrm{Si}_{085} \mathrm{O}_{4}$ & Stuffed Cristobalite & 2.578 & Orthorhombi & PDF \# 49-7 \\
\hline UNKNOWN & $\mathrm{Na}_{3} \mathrm{MgAlSi}_{2} \mathrm{O}_{8}$ & Stuffed Cristobalite & Not given & Orthorhombi & PDF \# 49-8 \\
\hline \multicolumn{6}{|l|}{ Sodalite Group } \\
\hline $2 \mathrm{NaCl}$ & $\mathrm{Na}_{6}\left[\mathrm{Al}_{6} \mathrm{Si}_{6} \mathrm{O}_{24}\right](2 \mathrm{NaCl})$ & Sodalite & $2.31^{*}$ & Cubic $^{*}$ & 12 \\
\hline $2 \mathrm{NaOH}$ & $\mathrm{Na}_{6}\left[\mathrm{Al}_{6} \mathrm{Si}_{6} \mathrm{O}_{24}\right](2 \mathrm{NaOH}) \bullet 1.5 \mathrm{H}_{2} \mathrm{O}$ & $\begin{array}{l}\text { Basic Sodalite or } \\
\text { Hydroxysodalite }\end{array}$ & $2.215^{* *}$ & $\mathrm{Cubic}^{* *}$ & 13 \\
\hline $2 \mathrm{NaNO}_{3}$ & $\mathrm{Na}_{6}\left[\mathrm{Al}_{6} \mathrm{Si}_{6} \mathrm{O}_{24}\right]\left(2 \mathrm{NaNO}_{3}\right)$ & Nitrated Sodalite & 2.342 & Cubic & PDF\#50-0248 \\
\hline $\mathrm{Na}_{2} \mathrm{SO}_{4}$ & $\mathrm{Na}_{6}\left[\mathrm{Al}_{6} \mathrm{Si}_{6} \mathrm{O}_{24}\right]\left(\mathrm{Na}_{2} \mathrm{SO}_{4}\right)$ & Nosean & $2.21^{\mathrm{tt}}$ & Cubic $^{\text {tt }}$ & 14 \\
\hline $\mathrm{xNaOH}+\mathrm{y} \mathrm{H}_{2} \mathrm{O}$ & $\mathrm{Na}_{6}\left[\mathrm{Al}_{6} \mathrm{Si}_{6} \mathrm{O}_{24}\right](\mathrm{xNaOH}) \bullet y \mathrm{H}_{2} \mathrm{O}$ & Basic Nosean & & & 13 \\
\hline $1-2(\mathrm{Ca}, \mathrm{Na}) \mathrm{SO}_{4}$ & $(\mathrm{Na})_{6}\left[\mathrm{Al}_{6} \mathrm{Si}_{6} \mathrm{O}_{24}\right]\left((\mathrm{Ca}, \mathrm{Na}) \mathrm{SO}_{4}\right)_{1-2}{ }^{\mathrm{t}}$ & Hauyne & $2.4^{\mathrm{t}}$ & Cubic $^{t}$ & 14 \\
\hline $\mathrm{x}(\mathrm{Ca}, \mathrm{Na})\left(\mathrm{S}, \mathrm{SO}_{4}, \mathrm{Cl}\right)$ & $\begin{array}{c}(\mathrm{Ca}, \mathrm{Na})_{6}\left[\mathrm{Al}_{6} \mathrm{Si}_{6} \mathrm{O}_{24}\right)_{\mathrm{x}}{ }^{\mathrm{t}}\left((\mathrm{Ca}, \mathrm{Na}) \mathrm{S}, \mathrm{SO}_{4}, \mathrm{Cl}\right. \\
\end{array}$ & Lazurite & 2.43 & Cubic & $\begin{array}{c}\text { PDF } \\
\# 17-749\end{array}$ \\
\hline \multicolumn{6}{|c|}{ Cancrinite Group } \\
\hline $2 \mathrm{NaNO}_{3}$ & $\mathrm{Na}_{6}\left[\mathrm{Al}_{6} \mathrm{Si}_{6} \mathrm{O}_{24}\right]\left(2 \mathrm{NaNO}_{3}\right)_{\bullet} 4 \mathrm{H}_{2} \mathrm{O}$ & Nitrated Cancrinite & 2.51 & Hexagonal & PDF \#38-513 \\
\hline$(\mathrm{Na}, \mathrm{Ca}, \mathrm{K})_{2} \mathrm{CO}_{3}$ & $\begin{array}{c}(\mathrm{Na}, \mathrm{Ca}, \mathrm{K})_{6}\left[\mathrm{Al}_{6} \mathrm{Si}_{6} \mathrm{O}_{24}\right]\left((\mathrm{Na}, \mathrm{Ca}, \mathrm{K})_{2} \mathrm{CO}_{3}\right. \\
)_{1.6} \bullet 2.1 \mathrm{H}_{2} \mathrm{O}\end{array}$ & Cancrinite & 2.60 & Hexagonal & PDF \#25-776 \\
\hline $2(\mathrm{Na}, \mathrm{K}) \mathrm{Cl}$ & $(\mathrm{Na}, \mathrm{Ca}, \mathrm{K})_{6}\left[\mathrm{Al}_{6} \mathrm{Si}_{6} \mathrm{O}_{24}\right](2(\mathrm{Na}, \mathrm{K}) \mathrm{Cl})_{2-3}$ & Microsommite & 2.34 & Hexagonal & $\begin{array}{c}\text { PDF } \\
\# 20-743 \\
\end{array}$ \\
\hline $2(\mathrm{Na}, \mathrm{K}) \mathrm{Cl}$ & $\begin{array}{c}(\mathrm{Na}, \mathrm{Ca}, \mathrm{K})_{6}\left[\mathrm{Al}_{6} \mathrm{Si}_{6} \mathrm{O}_{24}\right]\left((\mathrm{Na}, \mathrm{K})_{2} \mathrm{SO}_{4}, \mathrm{Cl}\right. \\
\end{array}$ & Davyne & 2.46 & Hexagonal & $\begin{array}{c}\text { PDF } \\
\# 20-379\end{array}$ \\
\hline $\mathrm{Na}_{2} \mathrm{CO}_{3}$ & $\mathrm{Na}_{6}\left[\mathrm{Al}_{6} \mathrm{Si}_{6} \mathrm{O}_{24}\right]\left(\mathrm{Na}_{2} \mathrm{CO}_{3}\right)$ & Natrodavyne & $\begin{array}{l}\text { Not } \\
\text { given }\end{array}$ & Hexagonal & $\begin{array}{c}\text { PDF } \\
\# 15-794\end{array}$ \\
\hline $\begin{array}{l}\text { PDF } \\
\text { PDF }\end{array}$ & $\begin{array}{l}\# 20-1087 \\
\# 17-538\end{array}$ & $\begin{array}{l}\text { DF \# 20-495 } \\
\text { DF \#11-401 }\end{array}$ & & $\$ 38-241$ & \\
\hline
\end{tabular}


WSRC-TR-2004-00532

Revision 0

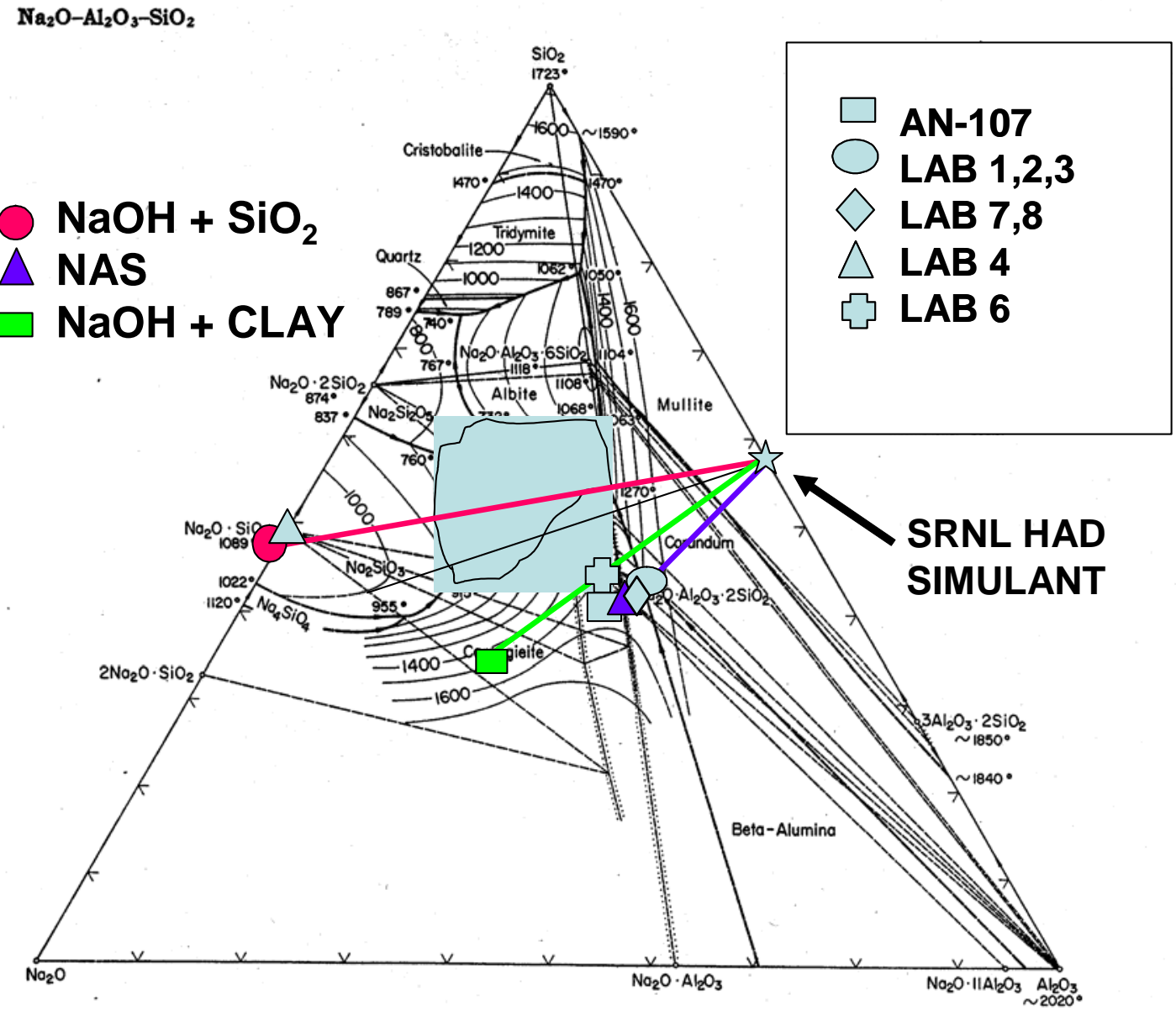

FIG. 501.-System $\mathrm{Na}_{2} \mathrm{O}-\mathrm{Al}_{2} \mathrm{O}_{2}-\mathrm{SiO}_{2}$; composite. E. F. Osborn and Arnulf Muan, revised and redrawn "Phase Equilibrium Diagrams of Oxide Systems," Plate 4, published by the
American Ceramic Society and the Edward Orton, Jr., Ceramic Foundation, 1960.

Principal References

G. W. Morey and N. L. Bowen, J. Phys. Chem., 28, 1167-79 (1924).

F. C. Kracek, J. Phys. Chem., 34, 1583-98 (1930).

. Ceram. Soc, 7, 238-54 (1924); corrections, ibid. 410

N. A. Toropov and F. Ya. Galakhov, Voprosy Petrogr. i Mineralog., A kad. Nauk S.S.S.R., 2, 245-55 (1953)

J. F. Schairer and N .

Liberto De Pablo-Galan and Wilfred R. Foster, J. Am. Ceram. Soc., 42, 491-98 (1959).

Figure 4-1. Ternary phase diagram for the $\mathrm{Na}_{2} \mathrm{O}-\mathrm{SiO}_{2}-\mathrm{Al}_{2} \mathrm{O}_{3}$ system 
WSRC-TR-2004-00532

Revision 0

Table 4-4. Summary of Steam Reformer Product Samples

\begin{tabular}{|c|c|c|c|c|c|c|c|c|c|c|}
\hline Sample ID & LAB-1 & LAB-2 & LAB-3 & LAB-4 & LAB-5 & LAB-6 & LAB-7 & LAB-8 & LAB-9 & LAB-10 \\
\hline $\begin{array}{l}\text { Desired } \\
\text { Steam Reformer } \\
\text { Product Form }^{\dagger}\end{array}$ & $\begin{array}{l}\text { Granular } \\
\text { NAS }\end{array}$ & $\begin{array}{l}\text { Granular } \\
\text { NAS }\end{array}$ & $\begin{array}{l}\text { Granular } \\
\text { NAS }\end{array}$ & $\begin{array}{l}\text { Granular } \\
\mathrm{Na}_{2} \mathrm{SiO}_{3}\end{array}$ & $\begin{array}{l}\text { Monolithic } \\
\text { CNAS }\end{array}$ & $\begin{array}{l}\text { Granular } \\
\text { NAS }\end{array}$ & $\begin{array}{l}\text { Granular } \\
\text { NAS }\end{array}$ & $\begin{array}{l}\text { Granular } \\
\text { NAS }\end{array}$ & $\begin{array}{l}\text { Monolithic } \\
\text { CNAS }\end{array}$ & $\begin{array}{l}\text { Monolithic } \\
\text { CNAS }\end{array}$ \\
\hline Steps & 1 & 2 & 3 & 1 & 1 & 1 & 1 & 1 & 1 & 1 \\
\hline $\begin{array}{l}\text { Simulant with } \\
\text { RCRA metals } \\
(\mathrm{mL})\end{array}$ & 47 & 47 & 47 & 85.7 & 35.7 & 35.7 & 47 & 47 & 71.43 & 71.43 \\
\hline $50 \% \mathrm{NaOH}(\mathrm{mL})$ & None & None & None & 8.57 & 3.57 & 3.57 & None & None & None & None \\
\hline $\begin{array}{l}\text { Sucrose } \\
\text { Stoichiometry }\end{array}$ & $2 X$ & $2 X$ & $2 X$ & $2 X$ & $2 X$ & $2 \mathrm{X}$ & $2 X$ & $2 X$ & $2 X$ & $2 X$ \\
\hline Sucrose (g) & 1.15 & 1.15 & 1.15 & 2.1 & 0.87 & 0.87 & 1.15 & 1.15 & 1.75 & 1.75 \\
\hline Reagent(s) & $\begin{array}{c}\text { Zeolite } \\
\text { A }\end{array}$ & $\begin{array}{c}\text { Zeolite } \\
\text { A }\end{array}$ & $\begin{array}{c}\text { Zeolite } \\
\text { A }\end{array}$ & $\begin{array}{l}\mathrm{NaOH}+ \\
\mathrm{SiO}_{2}\end{array}$ & $\begin{array}{c}\mathrm{NaOH}+ \\
\mathrm{OPC}\end{array}$ & $\begin{array}{l}\mathrm{NaOH}+ \\
\text { Clay }\end{array}$ & $\begin{array}{c}\text { Zeolite } \\
\text { A }\end{array}$ & $\begin{array}{c}\text { Zeolite } \\
\text { A }\end{array}$ & $\begin{array}{c}\text { Zeolite } \\
\mathrm{A}+ \\
\mathrm{OPC}\end{array}$ & $\begin{array}{c}\text { Zeolite } \\
\mathrm{A}+\mathrm{OPC}\end{array}$ \\
\hline $\begin{array}{l}\text { Grams Solid } \\
\text { Reagent }\end{array}$ & 9.37 & 9.37 & 9.37 & 4 & 7.5 & 7.5 & 13.399 & 13.822 & $95+100$ & $95+50$ \\
\hline $\begin{array}{l}\text { Additive Loading } \\
(\mathrm{wt} \%)\end{array}$ & 93 & 93 & 93 & 95 & 95 & 95 & 95 & 98 & 97.5 & 96.5 \\
\hline
\end{tabular}

${ }^{\dagger} \mathrm{NAS}=$ sodium aluminosilicate; CNAS = calcium sodium aluminosilicate; OPC = ordinary Portland cement; 


\subsection{Steam Reformer Product Fabrication in the SRNL Benchscale Steam Reformer}

The bench-top steam reformer (BSR) is a two-stage unit used to produce the same mineralized products and gases as a fluidized bed steam reformer (FBSR). A schematic of the unit is shown in figure 4-2.

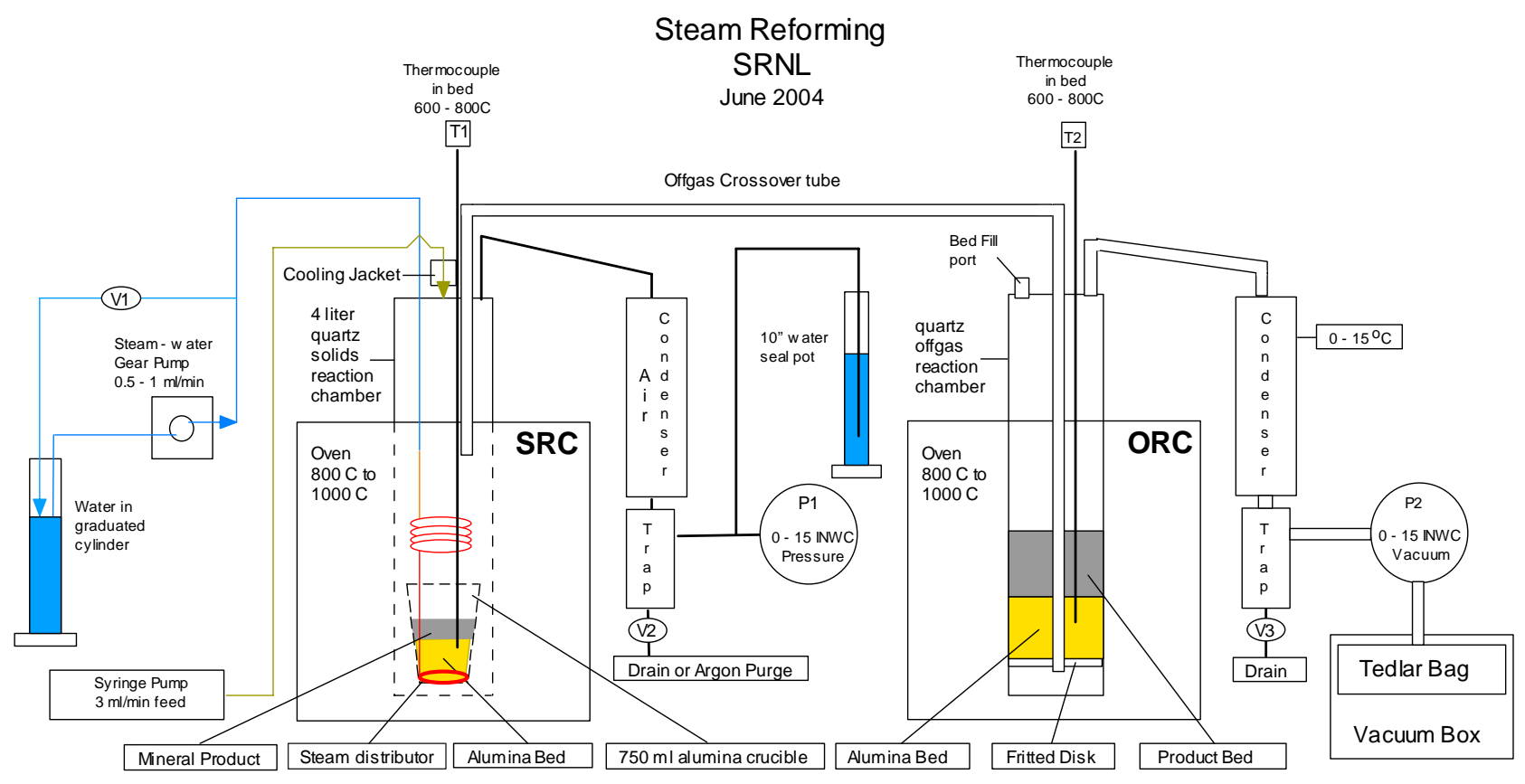

Figure 4-2. Schematic of the SRNL Benchscale Steam Reformer

The solids reaction chamber (SRC) holds a crucible into which a steam distributor, submerged in an alumina bed, is used to produce the superheated steam needed for the reactions. The premixed feed slurry is dripped into the crucible where the reactions take place.

Gases and steam leaving the crucible travel through an insulated crossover tube and into the Offgas Reaction Chamber (ORC) of the unit where the gases then go through more heated alumina before reacting with ground up product that comes from a previous run. The resulting steam is condensed and collected in a trap and the non-condensable gases are dried through desiccant before being collected in a Tedlar bag.

Two additional Steam Reformer products, LAB-7PB and LAB-10PB, were produced in SRNL's Benchscale Steam Reformer (BSR) The BSR was run at $725^{\circ} \mathrm{C}$ for 4 hours with the same coreactants and sucrose concentrations as indicated in Table 4-4. Lab waste \#7, a granular NAS waste form, and Lab waste \#10, a monolithic waste form, were both tested in the BSR. It was especially important to run one of the monolithic waste form tests in the BSR with real steam to ensure that the OPC used as a source for calcium and silica did not react in the continuous steam environment. 


\subsection{RESULTS}

\subsection{Granular FBSR Products}

\subsubsection{Zeolite A Additives}

The SRNL aqueous wastes only contain about $1.5 \mathrm{wt} \%$ total solids after evaporation and denitration. Therefore, the additives had to contain the necessary cations $\left(\mathrm{Na}^{+}\right.$and $\left.\mathrm{Ca}^{+2}\right)$ to complex the anion rich waste. The additive loadings were high but gave large volume reductions (Section 5.3). Laboratory experiments LAB 1, LAB 2, and LAB 3 had a 93\% additive loading while LAB 7 and LAB 8 had 95\% and 98\% additive loadings, respectively.

LAB 1 and $\mathrm{LAB} 2$ made the desired $\mathrm{Cl}$ host phase sodalite from the $\mathrm{HCl}$ in the HAD waste. The $\mathrm{X}$-ray Diffraction (XRD) analysis of LAB 1 and LAB 2 indicated that there was excess $\mathrm{NaCl}$ present in the product that did not get bound up in the preferred sodalite mineral host phase (Table 5-1) when tested in the crucibles by the one step and two step process. This may indicate that the additive loading is not sufficiently high enough, e.g. does not provide enough cations, to complex all the anions in the HAD waste or that the one and two step processes are insufficient at immobilization. LAB 3, the three step process, at 93\% additive loading made the desired phases without any excess $\mathrm{NaCl}$ (Table 5-1). This may be due to excess volatilization of the residual $\mathrm{NaCl}$ in the third step as shown in Table 5-2.

LAB 7 and LAB 8 made the desired sodalite and nepheline host phases when experiments using Zeolite $\mathrm{A}$ as the primary source of $\mathrm{Na}^{+}$were performed at 95 and $98 \%$ additive loadings using only the one step process (Table 5-1). These experiments also retained more $\mathrm{Cl}$ than the LAB 2 and LAB 3 samples (Table 5-2) indicating that the higher additive loadings are necessary to retain all the anions in the HAD waste.

Experiment LAB 7, at a 95\% Zeolite A additive loading was also fabricated in the BSR. The product sample from the $\mathrm{BSR}$ had residual $\mathrm{NaCl}$ in the pattern suggesting that a $98 \%$ additive loading is more reasonable to tie up all of the HAD anions in the cage like sodalite and nepheline phases. This sample retained more $\mathrm{Cl}$ than any of the crucible experiments (sample LAB 7PB in Table 5-2).

\subsubsection{NaOH and Kaolin Clay Additives}

Lab 6 was made from $\mathrm{NaOH}$ and OptiKasT kaolin clay (Table 4-4). It had a $\sim 95 \%$ additive loading and also produced the desired $\mathrm{Cl}$ rich sodalite and nepheline phases without any excess $\mathrm{NaCl}$ being observed in the XRD of the product (Table 5-1). This indicates that slightly higher concentrations of HAD waste may be solidified in the FBSR NAS phases if reacted with clay and $\mathrm{NaOH}$ instead of Zeolite-A so that the waste is incorporated during reaction of the $\mathrm{NaOH}$ and the clay. 


\subsubsection{NaOH and Silica Additives}

The attempt to make $\mathrm{Na}_{2} \mathrm{SiO}_{3}$ with the HAD simulant was not successful (LAB 4). While a different sodium silicate product was made $\left(\mathrm{Na}_{2} \mathrm{Si}_{2} \mathrm{O}_{5}\right)$, the major phase produced was $\mathrm{NaCl}$ with minor $\mathrm{NaF}$ and $\mathrm{SiO}_{2}$ as other products. This phase assemblage indicates that the $\mathrm{Cl}$ in the HAD waste sequestered the $\mathrm{Na}$ from the $\mathrm{NaOH}$ to form $\mathrm{NaCl}$ and $\mathrm{NaF}$ and the $\mathrm{SiO}_{2}$ remained unreacted.

\subsection{Monolithic FBSR Products}

\subsubsection{Zeolite A and Ca-Silicate Additives}

Experiments LAB 9 and LAB 10 attempted to make monolithic, naturally cementitious, waste forms from the SRNL aqueous HAD waste. In these tests both the Zeolite-A used in the granular tests and Portland cement were used as a source of cations and silica. In both of these tests the Zeolite-A additive was present at $95 \mathrm{wt} \%$. In LAB 9 an amount of Portland cement equal to the Zeolite-A was added to the HAD simulant before treatment. In LAB 10 the amount of Portland cement was $1 / 2$ the amount of the Zeolite-A added. LAB 9 and LAB 10 made the desired sodalite, nepheline, and calcium silicate (larnite) phases and contained some extra Portland cement phases (calcium aluminates and calcium aluminoferrites) which were expected (Table 5-1).

The LAB 10 formulation was also treated in the BSR to determine if the steam would affect the Portland cement. This was by far the most successful monolithic test performed in that the product phases were sodalite, nepheline, zeolite-A and larnite (Table 5-1). Moreover, the OPC did not react in the steam and a free flowing powder was produced.

After the samples were heat treated and ground they were set with water at a water to cement (W/C) ratio of $\sim 0.6[15]$ and left to cure for a month. All of the samples, LAB 9 (crucible), LAB 10 (crucible and BSR) all set into cylindrical waste forms (see Figure 5-1). The LAB 10 crucible sample did not set well but the LAB 10 BSR sample and the LAB 9 crucible samples set very well into cylinders that could be used for direct disposal.

\subsubsection{NaOH and Ca-Silicate Additives}

LAB 5 was made with $\mathrm{NaOH}$ and Portland cement using the cement and the $\mathrm{NaOH}$ as a source of cations but only using the cement as a source of silica and alumina. This experiment was not very successful in that excess $\mathrm{NaCl}$ from the HAD waste was the major phase observed (Table 5-1) along with other Portland cement phases such as calcium aluminoferrite (brownmillerite) and portlandite.

After this sample was heat treated and ground it was set with water at a water to cement $(\mathrm{W} / \mathrm{C})$ ratio of 0.6 [15] and left to cure for a month. Even though the $\mathrm{Cl}$ was still present as $\mathrm{NaCl}$ according to the XRD analyses, this sample set well into a cylindrical disc (see Figure 5-1 for a photo). This sample was set into a disc instead of a cylinder as a smaller amount of waste product had been made than LAB 9 and LAB 10. 


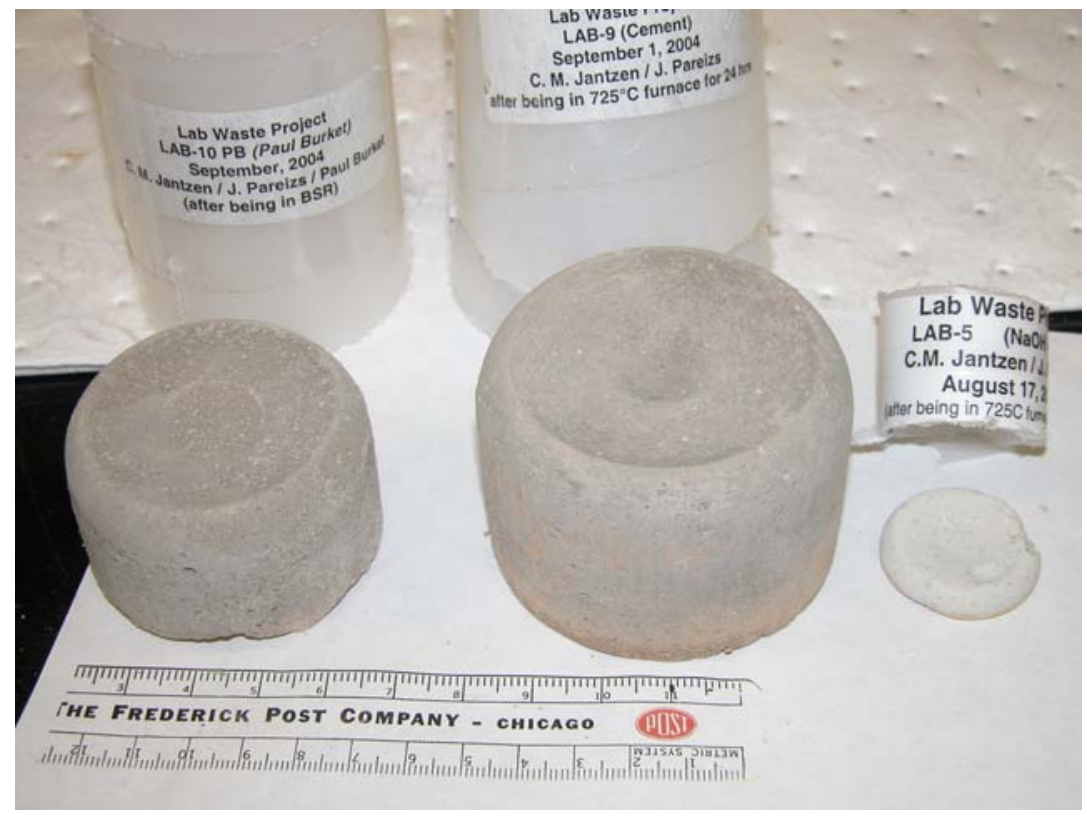

Figure 5-1. Photo of Monolithic FBSR Products (Lab 10, Lab 9, and Lab 5)

\subsection{Chemical Analyses}

Results of chemical analyses of the lab waste products are given in Table 5-2 (anions) and Table 5-3 (cations). All analyses were performed in duplicate since the FBSR product can be variable on a localized scale. For the aluminosilicate waste forms, sodium, aluminum and silicon were converted to oxides and normalized for comparison to the targeted composition. This comparison is given in Table 5-4. The comparison confirms that waste form compositions achieved were the compositions desired. Table 5-3 (cations) also indicates that the RCRA elements were retained in the waste form.

The anion analyses given in Table 5-2 show that:

- Nearly all the nitrate was destroyed. Additional sucrose or coal could be added to get higher destruction if necessary.

- Nearly all the chloride was retained (i.e., not volatized) during sample fabrication.

- Fluoride was volatilized during sample preparation

- Sulfate content was much higher than expected based on analyzed simulated HAD waste composition. This is likely due to sulfate that was present in the RCRA spike which was not analyzed. The results do show that sulfate had not volatized during processing; however, this cannot be quantified without analysis of the RCRA spike. 


\subsection{Volume Reductions/Increases}

Most of the LAB waste experiments afforded large volume reductions relative to the volume of the original HAD waste (see Table 5-5). For the granular products that can be recycled to a DWPF feed tank or a waste tank, the volume reductions range from 90-93\%. Therefore, a tanker truck of 4000 gallons of HAD waste would only make 280 gallons of solid granular waste product. However, there is only $3925 \mathrm{~L}$ (1037 gallons) of HAD waste generated in SRNL on a yearly basis. Therefore, FBSR of a years worth of HAD waste would create $\sim 104$ gallons of granular waste or $\sim 575 \mathrm{kgs}$ of solid waste per year assuming an FBSR product density of 1.46 $\mathrm{kg} / \mathrm{L}$. However, this waste would be highly radioactive.

For the monolithic FBSR products that may be acceptable for on site burial, one produced a volume decrease of 93\% (LAB 5) but the phases produced were poorly cementitious. LAB 9 and $\mathrm{LAB} 10$ which were cementitious produced volume increases of $48 \%$ and $9 \%$ respectively compared to the original HAD waste volume. 
Table 5-1. Summary of Steam Reformer Product Sample Results

\begin{tabular}{|c|c|c|c|c|c|c|}
\hline \begin{tabular}{r|} 
Sample \\
I \\
D
\end{tabular} & $\begin{array}{c}\text { Temp } \\
\left({ }^{\circ} \mathrm{C}\right)\end{array}$ & $\begin{array}{l}\text { Time } \\
\text { at } \\
\text { Temp }\end{array}$ & $\begin{array}{c}\text { Parr } \\
\text { Vessel } \\
\text { Treat }\end{array}$ & $\begin{array}{l}\text { Major Phase } \\
\text { Desired }\end{array}$ & $\begin{array}{c}\text { Major Phases Identified by X-Ray } \\
\text { Diffraction }\end{array}$ & $\begin{array}{c}\text { Minor Phases Identified by X-Ray } \\
\text { Diffraction }\end{array}$ \\
\hline \multicolumn{7}{|c|}{ Open Crucible Tests } \\
\hline LAB-1 & 725 & 24 & $\mathrm{NO}$ & Sodalite/Nepheline & $\begin{array}{c}\text { Sodalite }\left[\mathrm{Na}_{8}\left(\mathrm{AlSiO}_{4}\right)_{6} \mathrm{Cl}_{2}\right] \\
\text { Nepheline }\left[\mathrm{NaAlSiO}_{4}\right]\end{array}$ & $\mathrm{NaCl}$ \\
\hline LAB-2 & 725 & 24 & YES & Sodalite/Nepheline & $\begin{array}{c}\text { Sodalite }\left[\mathrm{Na}_{8}\left(\mathrm{AlSiO}_{4}\right)_{6} \mathrm{Cl}_{2}\right] \\
\text { Nepheline }\left[\mathrm{Na}_{6.65} \mathrm{Al}_{6.24} \mathrm{Si}_{9.76} \mathrm{O}_{32}\right]\end{array}$ & $\mathrm{NaCl}$ \\
\hline LAB-3 & 725 & 24 & YES & Sodalite/Nepheline & $\begin{array}{c}\text { Sodalite }\left[\mathrm{Na}_{8}\left(\mathrm{AlSiO}_{4}\right)_{6} \mathrm{Cl}_{2}\right] \\
\text { Nepheline }\left[\mathrm{NaAlSiO}_{4}\right]\end{array}$ & None \\
\hline LAB-4 & 725 & 24 & $\mathrm{NO}$ & $\mathrm{Na}_{2} \mathrm{SiO}_{3}$ & $\mathrm{NaCl}$ & $\mathrm{Na}_{2} \mathrm{Si}_{2} \mathrm{O}_{5}, \mathrm{NaF}$, Quartz $\left[\mathrm{SiO}_{2}\right]$ \\
\hline LAB-5 & 725 & 24 & $\mathrm{NO}$ & $\begin{array}{l}\text { Sodalite/Nepheline } \\
\text { and Ca-Silicates }\end{array}$ & $\mathrm{NaCl}, \mathrm{CaO}$, Larnite $\left[\mathrm{Ca}_{2} \mathrm{SiO}_{4}\right]$, & $\begin{array}{c}\text { Brownmillerite } \\
{\left[\mathrm{Ca}_{2} \mathrm{Fe}_{1.52} \mathrm{Al}_{0 \cdot 48} \mathrm{O}_{5}\right] \text { Portlandite }} \\
{\left[\mathrm{Ca}(\mathrm{OH})_{2}\right], \text { Perovskite }\left[\mathrm{CaTiO}_{3}\right]}\end{array}$ \\
\hline LAB-6 & 725 & 24 & $\mathrm{NO}$ & Sodalite/Nepheline & $\begin{array}{c}\text { Sodalite }\left[\mathrm{Na}_{8}\left(\mathrm{AlSiO}_{4}\right)_{6} \mathrm{Cl}_{2}\right] \\
\text { Nepheline }\left[\mathrm{Na}_{3} \mathrm{~K}\left(\mathrm{Al}_{0.44} \mathrm{Si}_{0.56}\right)_{8} \mathrm{O}_{16}\right]\end{array}$ & Anatase $\left[\mathrm{TiO}_{2}\right]$ Quartz $\left[\mathrm{SiO}_{2}\right]$ \\
\hline LAB-7 & 725 & 24 & $\mathrm{NO}$ & Sodalite/Nepheline & $\begin{array}{c}\text { Sodalite }\left[\mathrm{Na}_{8}\left(\mathrm{AlSiO}_{4}\right)_{6} \mathrm{Cl}_{2}\right] \\
\text { Nepheline }\left[\mathrm{NaAlSiO}_{4}\right] \\
\end{array}$ & None \\
\hline LAB-8 & 725 & 24 & $\mathrm{NO}$ & Sodalite/Nepheline & $\begin{array}{c}\text { Sodalite }\left[\mathrm{Na}_{8}\left(\mathrm{AlSiO}_{4}\right)_{6} \mathrm{Cl}_{2}\right] \\
\text { Nepheline }\left[\mathrm{NaAlSiO}_{4}\right] \\
\end{array}$ & None \\
\hline LAB-9 & 725 & 24 & $\mathrm{NO}$ & $\begin{array}{l}\text { Sodalite/Nepheline } \\
\text { and Ca-Silicates }\end{array}$ & $\begin{array}{c}\text { Sodalite }\left[\mathrm{Na}_{8}\left(\mathrm{AlSiO}_{4}\right)_{6} \mathrm{Cl}_{2}\right] \\
\text { Nepheline }\left[\mathrm{NaAlSiO}_{4}\right] \\
\text { Larnite }\left[\mathrm{Ca}_{2} \mathrm{SiO}_{4}\right]\end{array}$ & Brownmillerite $\left[\mathrm{Ca}_{2} \mathrm{Al}_{1.38} \mathrm{Fe}_{0.62} \mathrm{O}_{5}\right]$ \\
\hline LAB-10 & 725 & 48 & NO & $\begin{array}{l}\text { Sodalite/Nepheline } \\
\text { and Ca-Silicates }\end{array}$ & $\begin{array}{c}\text { Nepheline }\left[\mathrm{Na}_{6.65} \mathrm{Al}_{6.24} \mathrm{Si}_{9.76} \mathrm{O}_{32}\right] \\
\text { Larnite }\left[\mathrm{Ca}_{2} \mathrm{SiO}_{4}\right]\end{array}$ & $\begin{array}{l}\text { Calcium Aluminate } \\
{\left[4 \mathrm{CaO} \bullet 3\left(\mathrm{Al}_{2} \mathrm{O}_{3}\right)\right]}\end{array}$ \\
\hline \multicolumn{7}{|c|}{ Benchscale Steam Reformer } \\
\hline $\begin{array}{c}\text { LAB- } \\
7 \mathrm{~PB}\end{array}$ & 725 & 24 & NO & Sodalite/Nepheline & $\begin{array}{c}\text { Sodalite }\left[\mathrm{Na}_{8}\left(\mathrm{AlSiO}_{4}\right)_{6} \mathrm{Cl}_{2}\right] \\
\text { Nepheline }\left[\mathrm{NaAlSiO}_{4}\right]\end{array}$ & $\mathrm{NaCl}$ \\
\hline $\begin{array}{l}\text { LAB- } \\
10 P B\end{array}$ & 725 & 48 & NO & $\begin{array}{l}\text { Sodalite/Nepheline } \\
\text { and Ca-Silicates }\end{array}$ & $\begin{array}{c}\text { Sodalite }\left[\mathrm{Na}_{4} \mathrm{Al}_{3} \mathrm{Si}_{3} \mathrm{O}_{12} \mathrm{C}\right] \\
\text { Nepheline }\left[\mathrm{Na}_{3} \mathrm{~K}\left(\mathrm{Al}_{0.44} \mathrm{Si}_{0.56}\right)_{8} \mathrm{O}_{16}\right] \\
\text { Zeolite } 4 \mathrm{~A}\left[\mathrm{Na}_{92} \mathrm{Al}_{92} \mathrm{Si}_{100} \mathrm{O}_{384}\right] \\
\text { Larnite }\left[\mathrm{Ca}_{2} \mathrm{SiO}_{4}\right]\end{array}$ & None \\
\hline
\end{tabular}


Table 5-2. Anion Concentrations (wt \%) of SRNL HAD Waste Samples After Solidification

\begin{tabular}{|c|c|c|c|c|c|c|c|}
\hline Sample ID & $\begin{array}{c}\text { Mobile Lab } \\
\text { ID }\end{array}$ & $\mathbf{F}$ & $\mathrm{Cl}$ & $\mathrm{NO}_{2}$ & $\mathrm{NO}_{3}$ & $\mathrm{PO}_{4}$ & $\mathrm{SO}_{4}$ \\
\hline Lab-1 (A) & 04-1167 & $<0.100$ & 5.69 & $<0.100$ & 0.088 & $<0.010$ & 0.039 \\
\hline Lab-1 (B) & 04-1167 & $<0.100$ & 4.96 & $<0.100$ & 0.064 & $<0.010$ & 0.034 \\
\hline Lab-2 (A) & 04-1168 & $<0.100$ & 4.86 & $<0.100$ & 0.082 & $<0.010$ & 0.038 \\
\hline Lab-2 (B) & 04-1168 & $<0.100$ & 4.88 & $<0.100$ & 0.082 & $<0.010$ & 0.038 \\
\hline Lab-3 (A) & 04-1169 & $<0.100$ & 3.84 & $<0.100$ & 0.079 & $<0.010$ & 0.040 \\
\hline Lab-3 (B) & 04-1169 & $<0.100$ & 3.45 & $<0.100$ & 0.062 & $<0.010$ & 0.039 \\
\hline Lab-4 (A) & 04-1170 & 1.74 & 15.3 & $<0.100$ & 0.036 & $<0.010$ & $<0.010$ \\
\hline Lab-4 (B) & $04-1170$ & 1.74 & 15.3 & $<0.100$ & 0.037 & $<0.010$ & $<0.010$ \\
\hline Lab-5 (A) & 04-1171 & 0.694 & 5.97 & $<0.100$ & 0.039 & $<0.010$ & 1.80 \\
\hline Lab-5 (B) & 04-1171 & 0.733 & 6.04 & $<0.100$ & 0.040 & $<0.010$ & 1.78 \\
\hline Lab-6 (A) & $04-1172$ & $<0.100$ & 6.37 & $<0.100$ & 0.342 & $<0.010$ & 0.072 \\
\hline Lab-6 (B) & 04-1172 & $<0.100$ & 6.50 & $<0.100$ & 0.368 & $<0.010$ & 0.070 \\
\hline Lab-7 (A) & 04-1173 & $<0.100$ & 4.89 & $<0.100$ & 0.076 & $<0.010$ & 0.045 \\
\hline Lab-7 (B) & $04-1173$ & $<0.100$ & 4.88 & $<0.100$ & 0.076 & $<0.010$ & 0.045 \\
\hline Lab-7 PB (A) & 04-1174 & $<0.100$ & 6.67 & $<0.100$ & 0.087 & $<0.010$ & 0.043 \\
\hline Lab-7 PB (B) & 04-1174 & $<0.100$ & 6.38 & $<0.100$ & 0.076 & $<0.010$ & 0.043 \\
\hline Lab-8 (A) & 04-1175 & $<0.100$ & 4.52 & $<0.100$ & 0.088 & $<0.010$ & 0.046 \\
\hline Lab-8 (B) & $04-1175$ & $<0.100$ & 4.43 & $<0.100$ & 0.085 & $<0.010$ & 0.043 \\
\hline Lab-9 (A) & 04-1176 & $<0.100$ & 0.720 & $<0.100$ & 0.043 & $<0.010$ & 1.08 \\
\hline Lab-9 (B) & $04-1176$ & $<0.100$ & 0.699 & $<0.100$ & 0.041 & $<0.010$ & 0.658 \\
\hline Lab-10 (A) & 04-1177 & $<0.100$ & 0.924 & $<0.100$ & 0.040 & $<0.010$ & 0.937 \\
\hline Lab-10 (B) & 04-1177 & $<0.100$ & 0.975 & $<0.100$ & 0.051 & $<0.010$ & 0.980 \\
\hline Lab-10 PB (A) & 04-1178 & $<0.100$ & 0.937 & $<0.100$ & 0.044 & $<0.010$ & 0.834 \\
\hline Lab-10 PB (B) & 04-1178 & $<0.100$ & 0.927 & $<0.100$ & 0.042 & $<0.010$ & 0.830 \\
\hline
\end{tabular}


WSRC-TR-2004-00532

Revision 0

Table 5-3. Cation Concentrations (wt \%) of SRNL HAD Waste Samples After Solidification

\begin{tabular}{|c|c|c|c|c|c|c|c|c|c|c|c|c|c|c|c|c|c|c|c|}
\hline SamI & $\begin{array}{l}\text { obile } \\
\text { b ID }\end{array}$ & Ag & Al & As & Ba & Be & Ca & Cd & Cr & $\mathbf{K}$ & $\mathrm{Na}$ & $\mathbf{N i}$ & $\mathbf{P b}$ & S & Se & Si & $\mathbf{T i}$ & $\mathbf{V}$ & Zn \\
\hline$b-1$ & $04-1167$ & .010 & 3 & .010 & 007 & .001 & 062 & 0.010 & .026 & .094 & & .018 & 0.010 & 0.100 & 0.010 & 17.6 & .012 & 0.006 & .008 \\
\hline $\mathrm{L}$ & 1167 & .01 & 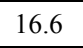 & 010 & 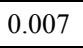 & .001 & 057 & $<0.010$ & 15 & .080 & 58 & 011 & 0.010 & $<0.100$ & $<0.010$ & 17.3 & .008 & .006 & .008 \\
\hline $\mathrm{Lab}$ & 68 & .01 & 12.7 & .010 & 207 & 0.0 & 045 & $<0.010$ & 013 & 0.064 & 16 & 0.010 & $<0.010$ & $<0.100$ & $<0.010$ & 13.3 & .006 & 0.006 & .011 \\
\hline $\mathrm{Lab}$ & 168 & 001 & .0 & .010 & 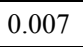 & 0.001 & 047 & $<0.010$ & 0.012 & 0.062 & 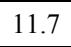 & 011 & .010 & $<0.100$ & $<0.010$ & 13.3 & .006 & 0.006 & 0.007 \\
\hline Lab-3 (A) & -1169 & $<0.010$ & 17.3 & $<0.010$ & 7 & 0.001 & .060 & $<0.010$ & 0.015 & 0.086 & 5.8 & 0.011 & $<0.010$ & $<0.100$ & $<0.010$ & 17.8 & 0.008 & 0.006 & 0.006 \\
\hline Lab- & 0 & $<0.010$ & 16.7 & $<0.0$ & 0 . & $<0.001$ & .061 & $<0.010$ & 16 & 0.088 & 15.2 & 13 & $<0.010$ & $<0.100$ & $<0.010$ & 17.7 & 0.008 & 0.006 & 0.007 \\
\hline Lab-4 & 04-1170 & $<0.010$ & 0.188 & $<0.010$ & 0.006 & $<0.001$ & 0.012 & $<0.010$ & 0.014 & $<0.010$ & 31.9 & 0.015 & $<0.010$ & $<0.100$ & $<0.010$ & 16.1 & 0.003 & 0.006 & 0.012 \\
\hline Lab-4 (B) & $04-1170$ & $<0.010$ & 0.183 & $<0.010$ & 0.006 & $<0.001$ & 0.014 & $<0.010$ & 0.015 & $<0.010$ & 31.3 & 0.013 & $<0.010$ & $<0.100$ & $<0.010$ & 16.0 & 0.004 & 0.006 & 0.010 \\
\hline Lab-5 (A) & 04-1171 & $<0.010$ & 1.74 & $<0.010$ & 0.023 & $<0.001$ & 28.9 & $<0.010$ & 0.016 & 0.219 & 13.4 & 0.013 & $<0.010$ & 0.592 & $<0.010$ & 5.78 & 0.090 & 0.024 & 0.019 \\
\hline Lab-5 (B) & -1171 & $<0.010$ & 1.76 & $<0.010$ & 0.023 & $<0.001$ & 28.9 & $<0.010$ & 0.015 & 0.215 & 14.4 & 0.013 & $<0.010$ & 0.605 & $<0.010$ & 5.86 & 0.095 & 0.024 & 0.027 \\
\hline Lab-6 (A) & -1172 & $<0.010$ & 15.8 & $<0.010$ & 0.010 & $<0.001$ & .049 & $<0.010$ & 0.021 & 0.097 & 17.5 & 0.013 & $<0.010$ & $<0.100$ & $<0.010$ & 16.0 & 0.681 & 0.017 & 0.007 \\
\hline Lab-6 (B) & -1172 & $<0.010$ & 16.0 & $<0.010$ & 0.010 & 0.001 & .059 & $<0.010$ & 0.022 & 0.094 & 17.7 & 0.012 & $<0.010$ & $<0.100$ & $<0.010$ & 16.2 & 0.711 & 0.017 & 0.009 \\
\hline Lab-7 (A) & $4-1173$ & $<0.010$ & 17.2 & $<0.010$ & 0.007 & $<0.001$ & 0.069 & $<0.010$ & 0.017 & 0.103 & 16.1 & 0.011 & $<0.010$ & $<0.100$ & $<0.010$ & 17.7 & 0.008 & 0.006 & 0.009 \\
\hline Lab-7 (B) & -1173 & $<$ & 17.4 & 0 & 0.0 & 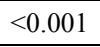 & 4 & $<0$. & 0 & 0.093 & -5 & 1 & 0 & 0 & 10 & 17.8 & .008 & .0 & 006 \\
\hline Lab-7 PB (A) & $04-11 / 4$ & $<0.010$ & 10.9 & $<0.010$ & 0.006 & $<0.001$ & 0.059 & $<0.010$ & 0.018 & 0.071 & 11.0 & 0. & $<0.010$ & $<0.100$ & $<0.010$ & 16.8 & 0.007 & 0.006 & 0.010 \\
\hline Lab-7 PB (B) & 04-1174 & $<0.010$ & 177 & $<0.010$ & 0.006 & $<0.001$ & 61 & $<0.010$ & & (2) & 16.2 & 0 . & $<0.010$ & $<0.100$ & $<0.010$ & 16.7 & 7 & 5 & .010 \\
\hline Lab-8 (A) & 04-1175 & $<0.010$ & 16.9 & $<0.010$ & 0.007 & $<0.001$ & 0.177 & $<0.010$ & & & 15.2 & & $<0.010$ & $<0.100$ & $<0.010$ & 17.4 & .009 & 5 & 0.006 \\
\hline Lab-8 (B) & 04-1175 & $<0.010$ & 17.2 & $<0.010$ & 0.007 & $<0.001$ & 0.060 & $<0.010$ & 0.013 & 0.091 & 15.4 & 0.009 & $<0.010$ & $<0.100$ & $<0.010$ & 18.0 & 0.007 & 0.006 & 0.005 \\
\hline Lab-9 (A) & $4-1176$ & $<0.010$ & 9.56 & $<0.010$ & 0.020 & $<0.001$ & 22.5 & $<0.010$ & 0.018 & 0.225 & 7.7 & 0.012 & $<0.010$ & 0.554 & $<0.010$ & 13.5 & 0.076 & 0.020 & 0.014 \\
\hline Lab-9 (B) & 04-1176 & $<0.010$ & 9.52 & $<0.010$ & 0.020 & $<0.001$ & 23.8 & $<0.010$ & 0.020 & 0.223 & 7.52 & 0.011 & $<0.010$ & 0.500 & $<0.010$ & 13.5 & 0.077 & 0.020 & 0.015 \\
\hline Lab-10 (A) & 4-1177 & $<0.010$ & 11.2 & $<0.010$ & 0.016 & $<0.001$ & 15.8 & $<0.010$ & 0.017 & 0.242 & 8.94 & 0.009 & $<0.010$ & .310 & $<0.010$ & 16.4 & 0.055 & 0.015 & 0.011 \\
\hline Lab-10 (B) & $04-1177$ & $<0.010$ & 11.0 & $<0.010$ & 0.016 & $<0.001$ & 15.2 & $<0.010$ & 0.017 & 0.254 & 9.21 & 0.010 & $<0.010$ & 0.312 & $<0.010$ & 16.3 & 0.054 & 0.015 & 0.013 \\
\hline Lab-10 PB (A) & 04-1178 & $<0.010$ & 13.1 & $<0.010$ & 0.016 & $<0.001$ & 13.6 & $<0.010$ & 0.015 & 0.167 & 9.93 & 0.027 & $<0.010$ & 0.283 & $<0.010$ & 14.7 & 0.052 & 0.015 & 0.011 \\
\hline Lab-10 PB (B) & 04-1178 & $<0.010$ & 13.5 & $<0.010$ & 0.016 & $<0.001$ & 14.0 & $<0.010$ & 0.015 & 0.171 & 10.1 & 0.047 & $<0.010$ & 0.285 & $<0.010$ & 14.5 & 0.058 & 0.014 & 0.012 \\
\hline
\end{tabular}


WSRC-TR-2004-00532

Revision 0

Table 5-4. Comparison Between Targeted and Measured Sodium, Aluminum, and Silicon Oxides in Lab Waste Samples

\begin{tabular}{|l|l|c|c|c|}
\hline \multicolumn{2}{|c|}{} & \multicolumn{3}{c|}{ Normalized Oxide $\mathbf{W t} \%$} \\
\cline { 3 - 5 } \multicolumn{2}{|c|}{} & $\mathbf{N a}_{\mathbf{2}} \mathbf{O}$ & $\mathbf{A l}_{\mathbf{2}} \mathbf{O}_{3}$ & $\mathbf{S i O}_{\mathbf{2}}$ \\
\hline \multirow{2}{*}{ Lab-1 (Crucible) } & Target & 23.3 & 35.1 & 41.5 \\
\cline { 2 - 5 } & Measured & 23.5 & 35.3 & 41.2 \\
\hline \multirow{2}{*}{ Lab-2 (Crucible) } & Target & 23.3 & 35.1 & 41.5 \\
\cline { 2 - 5 } & Measured & 22.9 & 35.5 & 41.6 \\
\hline \multirow{2}{*}{ Lab-3 (Crucible) } & Target & 23.3 & 35.1 & 41.5 \\
\cline { 2 - 5 } & Measured & 23.0 & 35.3 & 41.7 \\
\hline \multirow{2}{*}{ Lab-4 (Crucible) } & Target & 57.2 & 0.1 & 42.7 \\
\cline { 2 - 5 } & Measured & 55.1 & 0.5 & 44.4 \\
\hline \multirow{2}{*}{ Lab-6 (Crucible) } & Target & 24.0 & 34.1 & 42.0 \\
\cline { 2 - 5 } & Measured & 26.9 & 34.1 & 39.0 \\
\hline \multirow{2}{*}{ Lab-7 (Crucible) } & Target & 22.9 & 35.4 & 41.7 \\
\cline { 2 - 5 } & Measured & 24.2 & 35.1 & 40.8 \\
\hline \multirow{2}{*}{ Lab-7PB (BSR) } & Target & 22.9 & 35.4 & 41.7 \\
\cline { 2 - 5 } & Measured & 24.1 & 37.3 & 38.6 \\
\hline \multirow{2}{*}{ Lab-8 (Crucible) } & Target & 22.9 & 35.4 & 41.8 \\
\cline { 2 - 5 } & Measured & 22.7 & 35.5 & 41.7 \\
\hline
\end{tabular}

Table 5-5. Volume Reductions/Increases for FBSR HAD Products

\begin{tabular}{|c|c|c|c|c|c|}
\hline Sample ID & $\begin{array}{c}\text { Type of SR } \\
\text { Additive }\end{array}$ & $\begin{array}{c}\text { Type of SR } \\
\text { Product }\end{array}$ & $\begin{array}{c}\text { Bulk Density } \\
\text { Prod (Kg/L) }\end{array}$ & $\begin{array}{c}\text { Volume } \\
\text { Reduction } \\
\mathbf{( \% )}\end{array}$ & $\begin{array}{c}\text { Volume } \\
\text { Increase }\end{array}$ \\
\hline LAB WASTE 1, 2, 3 & Zeolite-A & Granular & $1.46^{*}$ & 93 & N/A \\
\hline LAB WASTE 4 & $\mathrm{NaOH+SiO} 2$ & Granular & $1.46^{*}$ & 92 & N/A \\
\hline LAB WASTE 5 & $\mathrm{NaOH+OPC}$ & Monolithic & $1.65^{* *}$ & 93 & N/A \\
\hline LAB WASTE 6 & NaOH+Clay & Granular & $1.46^{*}$ & 92 & N/A \\
\hline LAB WASTE 7 & Zeolite-A & Granular & $1.46^{*}$ & 90 & N/A \\
\hline LAB WASTE 8 & Zeolite-A & Granular & $1.46^{*}$ & 90 & N/A \\
\hline LAB WASTE 9 & Zeolite-A + OPC & Monolithic & $1.34^{* *}$ & N/A & 148 \\
\hline LAB WASTE 10 & Zeolite-A + OPC & Monolithic & $1.35^{* * *}$ & N/A & 109 \\
\hline
\end{tabular}

*value reported for granular FBSR bed product [6]; **value calculated from measured dimensions and weight. 


\subsection{CONCLUSIONS}

The FBSR technology was shown to be a suitable technology for disposal of SRNL HAD waste via any number of disposal paths. The FBSR technology is suitable for HAD waste disposal whether the technology is carried out in individual laboratory modules or in a centralized facility within SRNL. The latter, which provides for semi-continuous processing would be a more efficient method of HAD waste disposal.

The simplest batch laboratory crucible process is performed in a small muffle furnace with an 8 " by 8 " footprint. The one step process was shown to adequately make granular FBSR product when 95-98 wt\% Zeolite-A was added to SRNL aqueous laboratory waste (Tests LAB 7 and LAB 8) although the hydrothermal reactions that catalyze the FBSR product formation were not duplicated. Experiment LAB 7 was shown to be successful in the BSR at 95\% additive loading and would probably perform better at the $98 \mathrm{wt} \%$ additive loading of the LAB 8 formulation. These FBSR products make the desired sodalite and nepheline mineral host phases that sequester $\mathrm{Cl}, \mathrm{F}$, and $\mathrm{SO}_{4}$ from the HAD waste. The one step open crucible process was also shown to be successful when $\sim 95 \%$ of other additives (combined $\mathrm{NaOH} 50 \%$ solution and kaolin clay) were added to SRNL aqueous waste (LAB 6). These granular wastes reduce the HAD volume by 90$93 \mathrm{wt} \%$ so that it can be recycled to a DWPF process or waste tank.

Formation of $\mathrm{Na}_{2} \mathrm{SiO}_{3}$ from $\mathrm{NaOH} 50 \%$ solution and silica was not successful (Test LAB 4). Formation of a naturally cementitious FBSR product from HAD waste and Portland cement was also not successful (LAB-5) in that the desired mineral phases were not achieved. LAB-5 did however set when mixed with water although the material was still somewhat friable.

The FBSR process yields $90-93 \%$ volume reductions as demonstrated in this study. There is $\sim 3925 \mathrm{~L}$ of HAD waste generated in SRNL on a yearly basis. Therefore, FBSR of the HAD waste would create $\sim 575 \mathrm{kgs}$ of solid waste per year. These solids will likely have to be collected and recycled back to a waste or feed tank for subsequent vitrification in the Defense Waste Processing Facility (DWPF) because of the high doses of radioactivity associated with the large volume reductions or disposed of directly into a DWPF canister for burial at the federal Yucca Mtn. Repository. Recycle to DWPF would require a determination of the compatibility of the minerals produced with the DWPF process. Previous studies on SRS salt supernates have indicated that the carbonates and silicates are compatible with recycle to DWPF. Disposal at Yucca Mtn. would require qualification of the FBSR NAS mineral waste form as an alternative to vitrification. This study concentrated on producing the NAS FBSR mineral phases because these phases have the best anion and radionuclide retention, can be substituted for DWPF frit, and are the most flexible in terms of disposal paths.

The monolithic tests where both Zeolite-A and Portland cement were added before the FBSR roasting stage were successful and the resulting free flowing powder could be set with water for direct disposal in the SRS burial ground depending on the WAC and permitting issues. The monolithic tests produced volume increases of $9-48 \%$ which dilutes the radioactivity of the HAD waste monolith closer to acceptable WAC limits. 


\subsection{RECOMMENDATIONS/PATH FORWARD}

Based on the results and conclusions presented in this study, the following recommendations are made:

- Investigations of one or more successful formulations from this study should be verified with radioactive HAD wastes on both the batch scale and the semi-continuous BSR scale.

- The hazardous constituent spike used in this study should be analyzed so that the sulfate retention of the FBSR products produced in this study can be better quantified.

- Additional testing such as the Toxic Characteristic Leaching Procedure (TCLP), compressive strength, and Scanning Electron Microscopy (SEM) analyses on the naturally cementitious monoliths should be completed to evaluate the suitability of this form for land disposal.

- Alternative sources of calcium silicates should be investigated to make monolithic waste forms that are naturally cementitious to see if the monolith properties can be improved, e.g. compressive strength.

- Fabrication of sodium carbonate FBSR products which may be more compatible with recycle to a waste or feed tank for subsequent vitrification in DWPF should be evaluated.

- The use of sodium hydroxide and clay should be more fully investigated because only one test was performed with this combination of co-reactants and this combination of coadditives appeared more promising than the use of other NAS additives.

- Investigate the SRS burial ground Waste Acceptance Criteria (WAC) criteria for FBSR monolith disposal.

\subsection{ACKNOWLEDGEMENTS}

The authors would like to acknowledge the diligence of Sherry Vissage in performing the experiments and the photography. The authors would like to also acknowledge the rapid and thorough analyses performed by the SRNL Mobile Laboratory staff, David Best and Patricia Toole. 
WSRC-TR-2004-00532

Revision 0

\subsection{REFERENCES}

1 J.P. Bibler, et al., “A Waste Treatment Facility for 773-A Liquid Waste (U),” WSRCRP-89-1431, Westinghouse Savannah River Co., Aiken, SC (December 1989).

2 J.B. Mason, J. McKibben, J. Ryan, J. Schmoker, “ Steam Reforming Technology for Denitration and Immobilization of DOE Tank Wastes,” Waste Mgt. 03 (February 2003).

3 C.M. Jantzen, “Engineering Study of the Hanford Low Activity Waste (LAW) Steam Reforming Process,” U.S. DOE Report WSRC-TR-2002-00317, Westinghouse Savannah River Co., Aiken, SC (July 12, 2002).

4 B.P. McGrail, H.T. Schaef, P.F. Martin, D.H. Bacon, E.A. Rodriguez, D.E. McCready, A.N. Primak, and R.D. Orr, "Initial Evaluation of Steam-Reformed Low Activity Waste for Direct Land Disposal,” U.S. DOE Report PNWD-3288, Battelle Pacific Northwest Division, Richland, WA (January 2003).

5 C.M. Jantzen "Characterization and Performance of Fluidized Bed Steam Reforming (FBSR) Product as a Final Waste Form,” U.S. DOE Report WSRC-MS2003-00595, Rev. 0, Environmental Issues and Waste Management Technologies IX, J.D. Vienna and D.R. Spearing (Eds), Ceramic Transactions 155, 319-329 (2004).

6 D.W. Marshall, N.R. Soelberg, K.M. Shaber, “THORsm Bench-Scale Steam Reforming Demonstration,” U.S. DOE Report INEEL/EXT.03-00437, Idaho National Engineering \& Environmental Laboratory, Idaho Falls, ID (May 2003).

7 C.M. Jantzen, “Disposition of Tank $\mathbf{4 8 H}$ Organics by Fluidized Bed Steam Reforming (FBSR),” U.S. DOE Report WSRC-TR-2003-00352 (September 18, 2003).

8 C.M. Jantzen, “Fluidized Bed Steam Reforming of Organic and Nitrate Containing Salt Supernate,” U.S. DOE Report WSRC-MS-2004-00288, Environmental Issues and Waste Management Technologies X (in press).

9 C.M. Jantzen and P.R. Burket, "Feasibility of Fluidized Bed Steam Reforming (FBSR) for Savannah River Site (SRS) Salt Supernate,” U.S. DOE Report WSRC-TR-200400378 (July 2004).

10 E.M. Levin, et al., “Phase Diagrams for Ceramists Volume I,” American Ceramic Society, Columbus, OH (1964).

11 Kirk-Othmer Encyclopedia of Chemistry, Vol. 16 (1995).

12 W. A. Deer, R. A. Howie, and J. Zussman, “Rock-Forming Minerals, Vol IV,” John Wiley \& Sons, Inc., New York, 435pp. (1963). 
13 R. M. Barrer, J. W. Baynham, F. W. Bultitude, and W. M. Meier, "Hydrothermal Chemistry of the Silicates. Part V23I, Low-Temperature Crystal Growth of Aluminosilicates, and of Some Gallium and Germanium Analogues,” 195-208 (1959).

14 E.S. Dana, “A Textbook of Mineralogy,” John Wiley \& Sons, Inc., New York, 851pp (1932).

15 F.M. Lea, “The Chemistry of Cement and Concrete,” 3rd ed., Edward Arnold, Ltd., Great Britain (1970)

16 P.R. Burket, et al., "Evaluation of Steam Reforming Technology for Waste Treatment Using the Bench-Top Steam Reformer”, U.S. DOE Report WSRC-TR2004-00560, Westinghouse Savannah River Co., Aiken, SC (November, 2004). 
Distribution:

G. T. Wright, 773-A

L. M. Papuchado, 773-A

E. W. Holtzscheiter, 773-A

D. A. Crowley, 999-W

S. L. Marra, 999-W

J. C. Marra, 773-42A

T. B. Calloway, 999-W

N. E. Bibler, 773-A

C.M. Jantzen, 773-A

J. R. Harbour, 773-42A

G. G. Wicks, 773-A

A. D. Cozzi, 773-43A

C. A. Langton, 773-43A

T. W. Griffin, 773-43A

D. P. Skiff, 773-43A

A. A. Zagrodnik, 773-A

L. L. Eldridge, 773-43A

J. E. Young, 773-A

W. E. Daniel, 999-W

R. H. Spires, 766-H

B. C. Roger, 766-H 